\title{
Submarine earthquake rupture, active faulting and volcanism along the major Liquiñe-Ofqui Fault Zone and implications for seismic hazard assessment in the Patagonian Andes
}

\author{
Gabriel Vargas $^{1 *}$, Sofía Rebolledo ${ }^{1}$, Sergio A. Sepúlveda ${ }^{1}$, Alfredo Lahsen ${ }^{1}$, Ricardo Thiele ${ }^{1}$, \\ Brian Townley ${ }^{1}$, Cristóbal Padilla ${ }^{1}$, Rodrigo Rauld ${ }^{1}$, Maria José Herrera ${ }^{1}$, Marisol Lara ${ }^{1}$
}

\begin{abstract}
${ }^{1}$ Departamento de Geología, Facultad de Ciencias Físicas y Matemáticas, Universidad de Chile. Plaza Ercilla 803, Santiago, Chile. gvargas@ing.uchile.cl; srebolle@ing.uchile.cl; sesepulv@ing.uchile.cl; alahsen@ing.uchile.cl; rthiele@ing.uchile.cl; btownley@ ing.uchile.cl; cristobalpadilla@gmail.com; rodrigorauld@gmail.com; mariajoseherrera@gmail.com; marisoul@gmail.com *Corresponding author: gvargas@ing.uchile.cl
\end{abstract}

\begin{abstract}
The Liquiñe-Ofqui fault zone (LOFZ) in the Patagonian Andes is an active major transpressional intra-arc fault system along which Quaternary faulting and volcanism develop. Subaerial and submarine geomorphologic and structural characterization of latest Pleistocene-Holocene faults and monogenetic volcanoes allows us to assess geological cartography of active faults and the kinematic model for recent tectonics during postglacial times, since 12,000 cal. years BP. This allows increasing the basic geological knowledge necessary for determining the seismic hazard associated with cortical structures in the Aysén region in southern Chile. Fault cartography and field observations suggest dominant dextral-reverse strike slip along north-south and locally NNW-striking faults, dextral-normal strike slip along NE to NNE- striking faults, and sinistral strike slip along east-west faults. This kinematics is consistent with regional SW-NE shortening in the context of a major transpressional fault zone. Holocene and even historic monogenetic and sub-aquatic volcanism occurred in this tectonic setting in a close spatial relationship and probably favored by the activity and local architecture of faults. Submarine fault scarps and deformed sediments observed at the bottom of the Aysén Fjord were associated with the destructive April 2007 Mw6.2 earthquake located along the LOFZ. Our observations show that this earthquake occurred along dextral 15-20 km long N-S structure named Punta Cola Fault (PCF). This fault system is located some kilometres to the east of the main N-S Río Cuervo Fault (RCF). Most of the epicentres of the seismic swarm during 2007 were located along or in between both structures. The study area is a transference zone between N-S regional branches of the LOFZ. The cartography of fault segments proposed here together with geophysical and geologic data suggest that large earthquakes Mw6.2-6.5 can be typically expected along most of the active faults. Besides, seismic hazard assessment should also consider the possibility of earthquake magnitude in the order of 7.1 along the main fault systems like the RCF.
\end{abstract}

Keywords: Active faulting, Submarine earthquake rupture, Holocene volcanism, Triple junction, Patagonian Andes, Earthquake geology, Geological hazards. 
RESUMEN. Ruptura sísmica submarina, tectónica y volcanismo activo a lo largo de la Falla Liquiñe-Ofqui e implicancias para el peligro sísmico en los Andes patagónicos. La Zona de Falla Liquiñe-Ofqui es un sistema de intraarco activo y paralelo al contacto entre las placas tectónicas de Nazca y Sudamérica, a lo largo del cual el fallamiento y el volcanismo cuaternarios están estrechamente asociados. A partir de observaciones geomorfológicas y estructurales subaéreas, la prospección subacuática de fallas con evidencia de actividad pleistocena tardía-holocena y la caracterización de volcanes monogenéticos, se propone una cartografía y un modelo cinemático para la tectónica reciente, con énfasis en los últimos 12.000 años, asociada a fallas activas en el área del Fiordo Aysén. Esto permite incrementar sustancialmente el conocimiento geológico básico necesario para la determinación del peligro sísmico asociado a estructuras corticales en la región de Aysén de la Patagonia del sur de Chile. La cartografía de fallas junto con observaciones de campo y resultados geocronológicos sugieren que la deformación ocurre dominantemente a lo largo de estructuras de rumbo dextral-inversa de orientación norte-sur y localmente NNW-SSE, junto con fallas dextral-normal de rumbo NE a NNE y en menor medida a lo largo de fallas sinistrales de rumbo este-oeste. Es posible asociar esta cinemática a un acortamiento regional de orientación NE-SW. El volcanismo monogenético y subacuático holoceno ha ocurrido bajo este régimen tectónico, posiblemente favorecido por la geometría, estructura y cinemática de las fallas activas. Escarpes submarinos bien preservados de fallas que deforman sedimentos del fondo del fiordo Aysén fueron asociados con el terremoto de abril del año 2007, de magnitud Mw6,2, ocurrido a lo largo de la Zona de Falla Liquiñe-Ofqui. Observaciones realizadas en este estudio muestran que este terremoto ocurrió a lo largo de una falla de 15-20 km de largo de orientación norte-sur denominada Falla Punta Cola (FPC). Este sistema se localiza unos kilómetros al este de un sistema mayor de orientación norte-sur denominado Falla Río Cuervo (FRC). La mayoría de los epicentros de los terremotos y temblores durante la crisis sísmica del año 2007 ocurrieron entre estas estructuras o a lo largo de ellas. El área de estudio es una zona de transferencia entre sistemas regionales de orientación N-S de la Zona de Falla Liquiñe-Ofqui. La cartografía de segmentos de falla junto con datos geológicos y antecedentes geofísicos sugiere que terremotos de magnitud del orden de Mw6,2-6,5 son típicamente esperables a lo largo de la mayoría de los sistemas activos descritos en este trabajo. Además de esto, en los sistemas principales como a lo largo de la FRC, es posible esperar terremotos de magnitud del orden de Mw7,1, lo cual debería ser considerado en la evaluación del peligro sísmico de la región.

Palabras clave: Fallas activas, Ruptura sísmica submarina, Volcanismo activo, Punto triple, Andes patagónicos, Geología de terremotos, peligros geológicos.

\section{Introduction}

Earthquake size and occurrence in active fault systems result from regional and local stress field, fault kinematics and fault architecture, which is closely associated to structurally-controlled permeability and fluids (Scholz, 1982; Wells and Coppersmith,1994; Caine et al., 1996; Kim et al., 2004). Along the Liquiñe-Ofqui fault zone in the Patagonian Andes, close to the subduction of the Nazca and Antarctic plates beneath the South American plate, active faulting and volcanism seem closely associated with tectonically driven fluid circulation through exhumed basement rocks along the magmatic arc, which result in seismic activity and large earthquakes (Cembrano et al., 2002; Lange et al., 2008; Cembrano and Lara, 2009; Legrand et al., 2011). The close relationship between Quaternary faults and volcanic activity along this fault zone (Lara et al., 2008; Cembrano and Lara, 2009), suggest that the circulation of fluids with a possible magmatic component can plays a role in the generation of earthquakes along this fault zone (Legrand et al., 2011). Here, we assess the cartography and kinematics of Late PleistoceneHolocene fault systems and spatially associated monogenetic volcanic centres in the Aysén Fjord area of southern Chile, with the aim to improve critic knowledge for seismic hazard assessment in the Patagonian Andes.

The Liquiñe-Ofqui fault zone (LOFZ) is a major trench parallel intra-arc fault system which is recognized for more than 1,200 km along southern Chile, between $38^{\circ} \mathrm{S}$ and the triple junction of the Nazca, South American and Antarctic plates at ca. $47^{\circ} \mathrm{S}$ (Hervé, 1976, 1994; Forsythe and Nelson, 1985; Cembrano et al., 1996, 2002; Rosenau et al., 2006; Fig. 1). The right lateral strike-slip, oblique slip, reverse slip ductile to brittle deformation characterizing a transpressional regime along this system has been active during the late Cenozoic (Cembrano et al., 1996, 2002; Lavenu and Cembrano, 1999; Arancibia et al., 1999; Thomson, 2002; Rosenau et al., 2006; Adriasola et al., 2006), associated to 


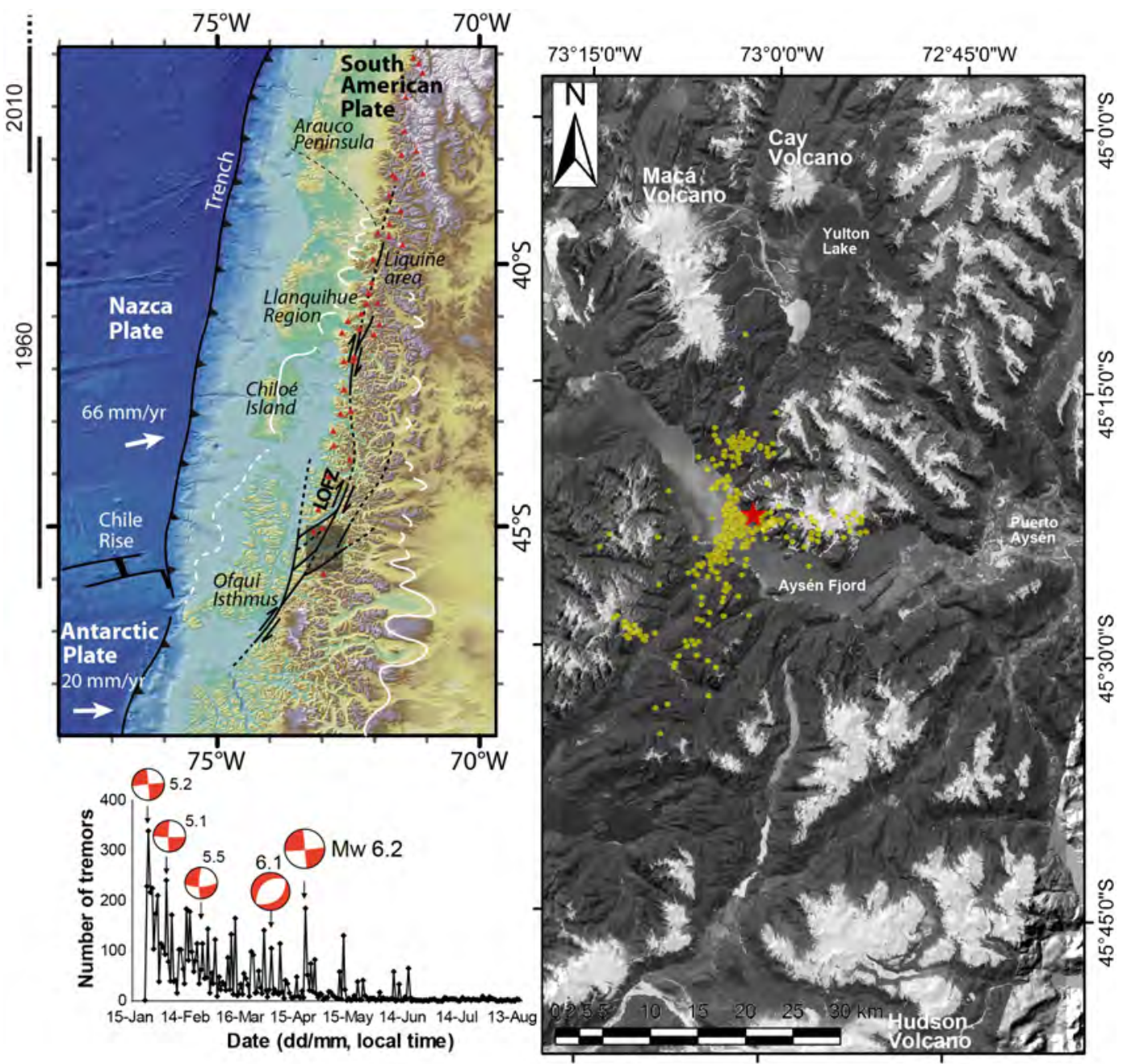

FIG. 1. Regional tectonic context at the triple junction of the Nazca, Antarctic and SouthAmerican plates, and location of the 2007 seismic swarm that occurred in the Patagonian Andes. Left top: Regional tectonic plate's context of the Patagonian Andes, indicating the main regional trace of the intra-arc Liquiñe-Ofqui Fault Zone and Late Pleistocene-Holocene large volcanoes (LOFZ; Forsythe and Nelson, 1985; Hervé, 1994; Cembrano et al., 1996, 2002; Arancibia et al., 1999; Thomson, 2002; Adriasola et al., 2006; Rosenau et al., 2006; Stern et al., 2007; Melnick et al., 2009). Black lines to the left show the latitudinal rupture of the 1960 Valdivia earthquake (Plafker and Savage, 1970; Kanamori, 1977; Cifuentes, 1989), and the 2010 Maule earthquake (Farías et al., 2010; Vargas et al., 2011; Vigny et al., 2011). White lines show the approximate maximum extend of the Pleistocene ice sheet during the Last Glacial Maximum (modified from Thomson et al., 2010). Right: Location of the April 2007 seismic swarm in the area of the Aysén Fjord (Legrand et al., 2011), and the relief shown by the means of a SPOT satellite image over a Digital Elevation Model (DEM). Circles represent seismic events of Mw $\leq 3.0$, as well as some events of Ms>5. The red star indicates the location of the main shock (Mw 6.2), according to GUC (2007). The location of the Macá, Cay and Hudson volcanoes is also shown. Left bottom: Distribution of number of events versus time, and focal mechanisms for the main shocks according to GUC (2007) and HRV (2007).

the oblique northeasterly $\left(\mathrm{N} 77^{\circ} \mathrm{E}\right)$ subduction of the Nazca plate beneath the South American plate, with an average of $66 \mathrm{~mm} / \mathrm{yr}$ at present (Angermann et al., 1999). South of $46-47^{\circ} \mathrm{S}$, the convergence margin is characterized by orthogonal subduction of the Antarctic plate beneath the South American plate at an average rate of $20 \mathrm{~mm} / \mathrm{yr}$ (DeMets et al., 1994).

Besides oblique subduction contact, strong interplate coupling, thermally weak continental crust, and 
the subduction of the Chile Ridge may have also an influence on the Pliocene to Quaternary tectonics of the LOFZ (Forsythe and Nelson, 1985; Cembrano et al., 2002).

The Andean subduction margin of south-central Chile produces large and megathrust earthquakes along the plate interface. Among the most recent events are the large earthquakes of Concepción in 1835 (Mw 8.5; Lomnitz, 1971; Beck et al., 1998), Maule 2010 (Mw 8.8; Madariaga et al., 2010; Farías et al., 2010; Moreno et al., 2010; Vargas et al., 2011; Vigny et al., 2011), and the giant Mw 9.51960 Valdivia earthquake (Plafker and Savage, 1970; Kanamori, 1977; Cifuentes, 1989). While the Concepción and Maule earthquakes ruptured for almost $500 \mathrm{~km}$ along the subduction contact located to the north of the Arauco Peninsula (Fig. 1), the seismic rupture of the Valdivia earthquake propagated for about 1,000 $\mathrm{km}$ along the subduction margin from the southern part of this peninsula $\left(38^{\circ} \mathrm{S}\right)$ towards the triple plate junction, which coincides with the latitudinal extent of the LOFZ (Plafker and Savage, 1970; Barrientos and Ward, 1990; Melnick et al., 2009). Based on geological, seismological and geodetic data, the LOFZ has been considered the eastern boundary of a fore-arc sliver characterized by northward displacement and decoupled from stable South America (Wang et al., 2007; Melnick et al., 2009), with a northern limit that should be a buttress located at the latitude of Arauco Peninsula (37º S, Fig. 1; Melnick et al., 2009).

The regional tectonic setting, together with strong erosion associated to Quaternary glaciation and deglaciation processes (Heusser, 1990; Denton et al., 1999), has controlled the geomorphologic evolution of the Patagonian Andes, including the exhumation of Miocene granitoids of the Patagonian batholith along the LOFZ (Pankhurst et al., 1992; Thomson, 2002; Adriasola et al., 2006; Thomson et al., 2010). In most of the Patagonian Andes, these rocks constitute the basement for the volcanic arc of the Southern Volcanic Zone (SVZ; López-Escobar et al., 1993, 1995; Stern, 2004), where faulting, volcanism and crustal seismicity are spatially associated (Cembrano et al., 1996; Lange et al., 2008; Cembrano and Lara, 2009; Legrand et al., 2011). The Quaternary volcanism along the $\mathrm{SVZ}$ between $37^{\circ}$ and $46^{\circ} \mathrm{S}$ is mainly basaltic to andesitic, with some explosive products of more silicic composition (López et al., 1995; Cembrano and Lara, 2009). This kind of volcanism is closely associated to NNE and NE-striking tension cracks with primitive minor Holocene monogenetic eruptive cones aligned along the master faults of the LOFZ (Lara et al., 2008; Cembrano and Lara, 2009), like the historically active Llaima volcano which developed along a NE fissural range with almost 40 minor centres aligned along a NE-striking arc structure (Moreno and Naranjo, 2003; Naranjo and Moreno, 2005). According to Lara et al. (2006) and Cembrano and Lara (2009), dacitic to rhyolitic volcanism can result from more complex evolution in some cases associated with WNW-striking basement structures like the Puyehue-Cordón Caulle, which is a NW-striking central volcano and fissure system associated to the LOFZ that experienced large explosive eruptions on 1960 and since 2011. The recent tectonic history of the Patagonian Andes includes destructive crustal earthquakes like the 2007 seismic swarm occurred at $45.5^{\circ} \mathrm{S}$, which was closely associated with master faults of the LOFZ (Barrientos et al., 2007; Comte et al., 2007; Cembrano et al., 2007; Mora et al., 2008; Legrand et al., 2011). Since January 2007 and during subsequent months, thousands of shallow earthquakes with focus located up to 9-10 km depth were recorded by local seismic network deployed in the Aysén Fjord and surrounding region (GUC, 2007; Barrientos et al., 2007; Legrand et al., 2011; Fig. 1). After an earthquake Mw5.3 occurred on January $23^{\text {rd }} 2007$, the greatest magnitudes increased through time (5.3, 5.2, 5.3, 5.7, 6.1, 6.2) within the following three months (Legrand et al., 2011). The last Mw 6.2 earthquake triggered rock slides of $c a$. 17-22, 7 and 2 million cubic metres volume, which occurred in a ravine next to Punta Cola and in front of Isla Mentirosa on the northern shore of the fjord (Fig. 2), and in front of Punta Cola on the southern shore of the fjord, respectively (Clavero et al., 2008; Sepúlveda and Serey, 2009; Naranjo et al., 2009; Sepúlveda et al., 2010; Yugsi Molina et al., 2012). While the first reached the fjord as a large debris avalanche, the second and third discharged directly into the basin, locally generating large tsunami waves that produced casualties and damage to salmon farms (Sepúlveda and Serey, 2009; Naranjo et al., 2009).

Given the timing, magnitude and energy distribution of seismicity, together with the focal mechanism of the six largest earthquakes, mainly NS to NNE dextral strike-slip with one NE normal slip (GCMT catalogue, 2007), this seismic swarm was interpreted as the result of the movement of fluids that at the same time reactivated strike-slip and normal faults 

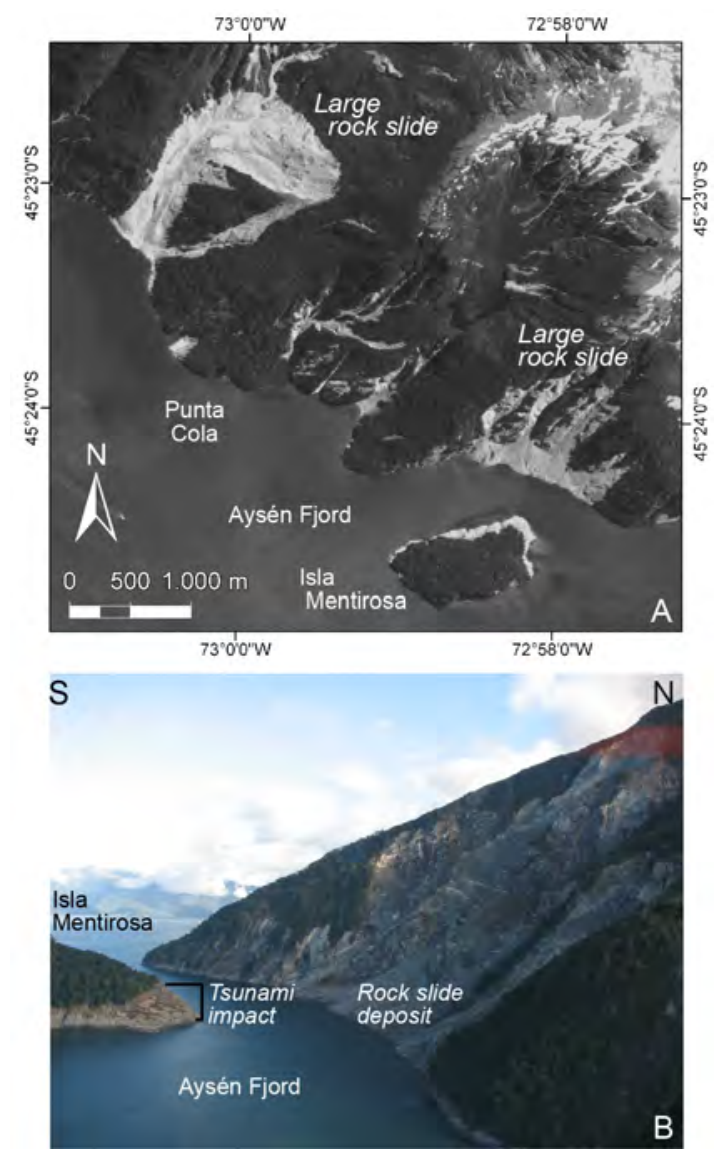

FIG. 2. SPOT satellite image and photographs showing the area where the largest rockslides occurred during the main earthquake on April 21, 2007, as well as the impact of the tsunami waves generated during this event.

of the LOFZ (Legrand et al., 2011). The inferred magmatic component as one of the possibilities for the origin of those fluids should be compatible with the presence of many monogenetic volcanic cones and complex Quaternary volcanoes in the area (Legrand et al., 2011), including the fjord itself (Lara, 2009).

In this paper we show submarine and subaerial evidence of co-seismic surface rupture associated to the last seismic swarm and previous events in the Aysén Fjord, and we provide geomorphologic, structural and geochronological evidence for a close spatial relationship between Holocene volcanic and tectonic activity along the LOFZ. Through detailed surface mapping of postglacial geomorphologic features affected by faults, together with field observations of mesoscale outcrops of faults affecting rocks and sediments, we propose a cartography of active fault segments and a kinematic model for recent tectonics, providing new data for seismic hazard assessment in one of the most important urban and commercial areas in the Aysén region of southern Chile.

\section{Methods and source of data}

Using a $3.5 \mathrm{kHz}$ chirp-system sub-bottom profiler (Bathy, 2010), we obtained bathymetric and high-resolution seismic reflection data from the upper $\sim 50-200 \mathrm{~m}$ of the sedimentary infill from the Aysén Fjord and surrounding lakes, near Puerto Aysén (Fig. 3). These techniques provides information about the stratigraphy of sediments that forms the subsurface of the sea bottom and about the structures that affect the sediments, at vertical resolution that, in terms of distance and in favourable cases such as laminated fine sediments, can be of $0.5 \mathrm{~m}$ and even as fine as $8 \mathrm{~cm}$. Field campaigns were carried out during 2008, using the R/V Petrel from Forest National Corporation (Corporación Nacional Forestal de Chile, CONAF). Complementary bathymetric information from the Aysén Fjord was obtained from the Chilean Navy Hydrographic and Oceanographic Survey (SHOA; 1:50,000 nautical chart No. 8106).

Surface neotectonic analysis was performed from imagery through the study of aerial photographs $(1: 70,000)$ and satellite images (SPOT, 2008, 10 and 2.5 m pixel resolutions; Landsat, 2001, 15 m pixel resolution), as well as from Digital Elevation Model (DEM). DEM (30 m horizontal resolution) obtained from 1:50,000 local topographic sheets from the Chilean Army Geographic Institute (IGM; 1:50,000 topographic charts Nos. I94- I96, I105-I107, I117I119, and I129-I131). DEMs obtained from the Shuttle Radar Topographic Mission dataset were also used to complete the observations concerning the main geomorphologic features in the area. Fieldwork and aerial recognition including the study in the field of the accessible outcrops complemented this analysis.

The most important faults were determined through the cartography of recent tectonic forms, like lineaments and fault scarps affecting glacial or postglacial geomorphologic units, complemented with structural observations and local kinematic measurements, as well as with observations from sub-bottom profile data from the Aysén Fjord and 


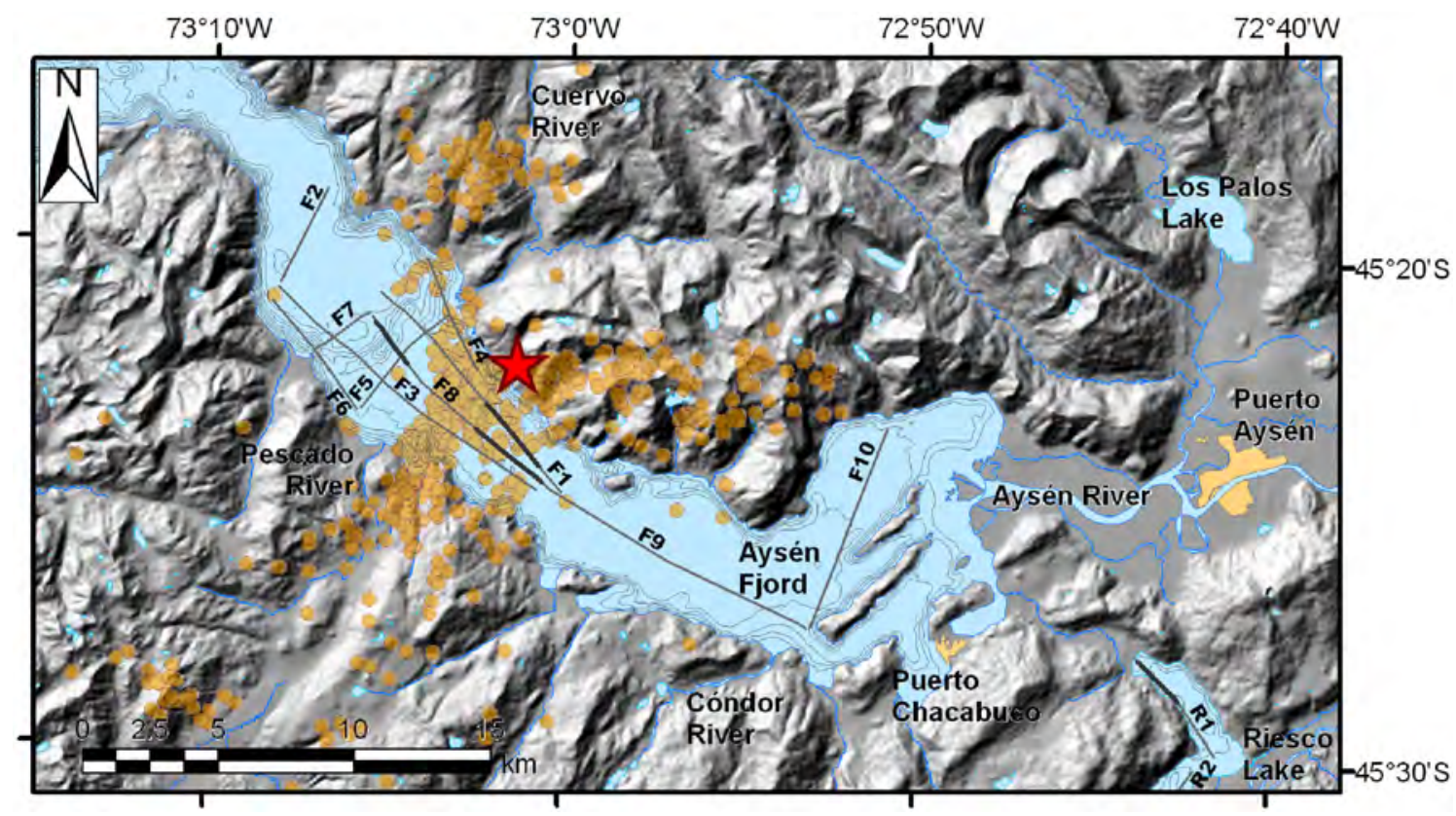

FIG. 3. Location of the sub-bottom seismic profiles obtained from the Aysén Fjord and Riesco Lake, using a 3.5 KHz (Bathy, 2010) device in the area of the 2007 seismic swarm (GUC, 2007), and subaerial and submarine reliefs shown by the means of a Digital Elevation Model, based on 1:50,000 topographic sheets from the Chilean Army Geographic Institute (IGM) and bathymetric information from the Chilean Navy Hydrographic and Oceanographic Survey (SHOA). The figure shows the location of the epicentres of the seismic events (yellow circles) and the epicentre of the Mw 6.2 earthquake (red star), according GUC (2007) and Legrand et al. (2011). Selected segments from profiles F1, F8 and R1 are shown in figures 4, 5 and 11, respectively.

surrounding lakes. In particular, the timing for the last Pleistocene ice sheet retreat in this area of the Patagonian Andes has been poorly assessed. In this work we show evidence that provide a temporal framework for the assessment of postglacial features affected by faults. Because of the vegetation cover and due to the strong erosional and depositional dynamics associated with the humid climate of the western slope of the Patagonian Andes (3,000-4,000 mm of annual rainfall), the preservation and hence the observation of outcrops associated with recent fault scarps and other geomorphologic features affected by tectonics is generally difficult. Thus, the lineaments or fault scarps affecting or cutting alluvial or glacial units provide direct evidence for recent tectonics. Radiocarbon results from organic debris and sediments analysed in Beta Analytic Inc. provided additional chronological key information for understanding recent fault kinematics. To express ages in calendar years (cal. years Before Present, i.e., before the year Anno Domini, 1950) conventional radiocarbon results were calibrated using Calib Calibration Program (Stuiver and Reimer, 1993), for terrestrial samples formed in the southern hemisphere (McCormac et al., 2004). Therefore, the fault cartography proposed in this work provides a new and detailed representation of fault segments constituting the main structural systems, showing evidences of superficial ruptures during the latest Pleistocene and Holocene times in the area. The differentiation between observed and inferred fault segments that resulted from this geologicalgeomorphic mapping considers subjective criteria with respect to the degree and nature of observations (from imagery, field outcrops and indirect observations from subbottom profiles) that supports the proposed fault cartography at scale 1:50,000.

The geomorphology of monogenetic volcanic cones was analysed following the morphometric methods proposed by Tibaldi (1995), with the aim to test their association with recent tectonic features in the area. Together with their alignment, the morphometry of pyroclastic cones can be used to infer the geometry of fracture feeding of magma to the cones (Tibaldi, 1995; Corazzato and Tibaldi, 2006). The base length and width together with axis orientations of the cones were mapped from 
SPOT satellite images and DEM, from which the elongation or degree of ellipticity using the ratio between the length of minor and major cone base axes was obtained. This was done for a total of 40 monogenetic cones, both as a whole and separated by geographically distributed groups.

\section{Submarine evidence of seismic rupture in the Aysén Fjord}

Subbottom profiles evidenced different seismic facies, which can be related to different geomorphologic and stratigraphic context. Massive to poorly laminated seismic reflection facies constitute most of the sedimentary infill of marine and lacustrine basins in the area, while well-stratified seismic reflection facies were observed close to the main riverine dis- charges, like the Aysén River and Cuervo River (Figs. 4 and 5). Chaotic seismic reflection facies were associated with moraine and landslide deposits, and stratified deformed sediments were observed near Punta Cola, to the east of the Cuervo River (Fig. 4). From the analysis of seismic reflection data we defined two units that forms the upper sedimentary infill of the fjord bottom (Figs. 4 and 5): the Lower Unit (of $>50 \mathrm{~m}$ thick) constituted by massive or poorly stratified seismic facies and the Upper Unit (of $c a$. $25 \mathrm{~m}$ thickness) formed by well-stratified and locally deformed sediments (Fig. 4). Considering that massive seismic facies can be associated with massive sandy sediments that constitute for example fluvial terraces of the Aysén River at Puerto Aysén, we interpret that the Lower Unit is most probably composed of sandy facies, while the Upper Unit of alternating sandy and
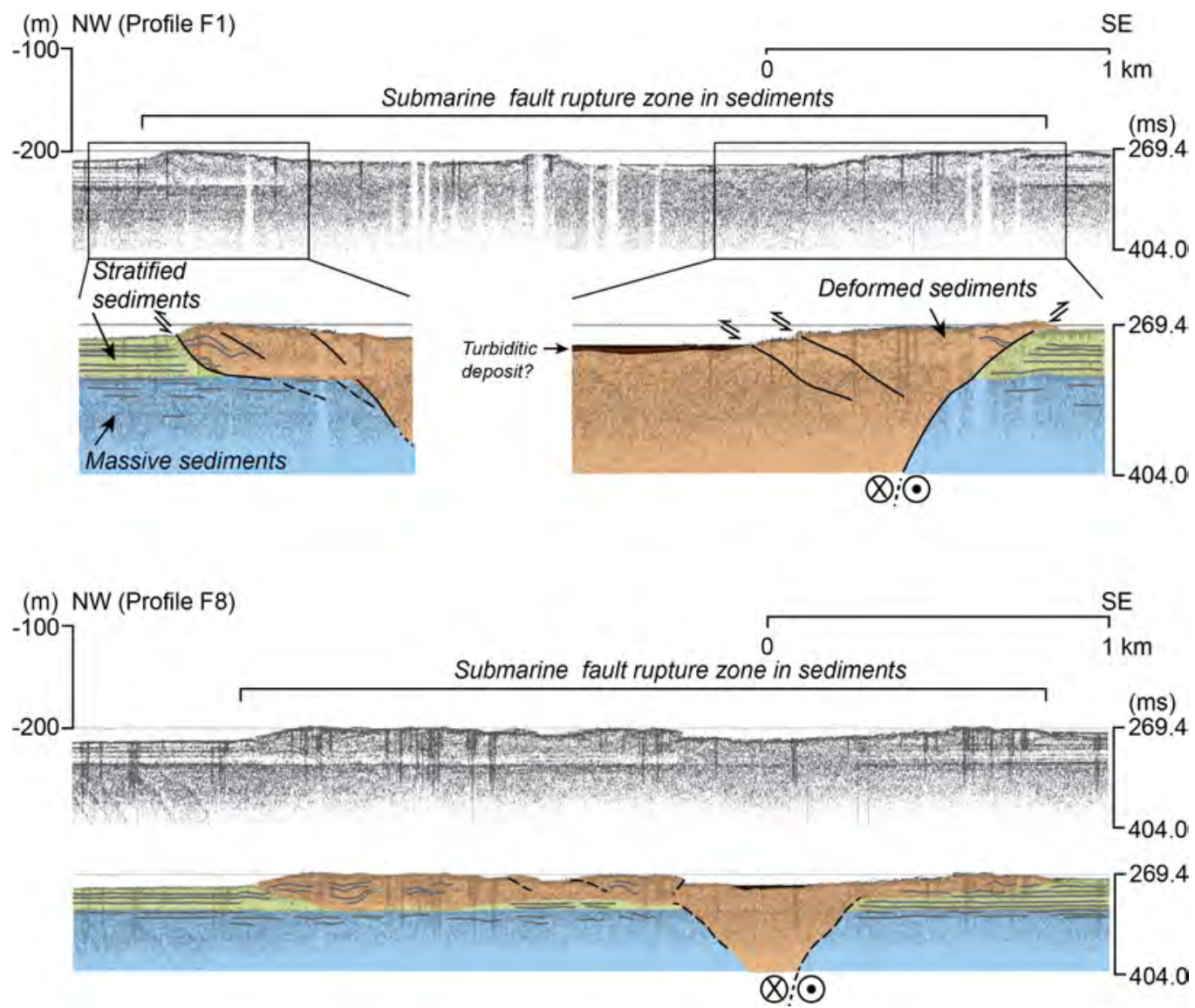

FIG. 4. Selected segments from sub-bottom profiles F1 and F8 from the Aysén Fjord (location in Fig. 3), showing fresh submarine fault scarps and deformed sediments in the area of the Mw 6.2 earthquake, along the Punta Cola Fault (Fig. 6). Massive and stratified sediments correspond to the Lower and Upper units respectively, of the sedimentary infill of the Aysén Fjord (see text). 


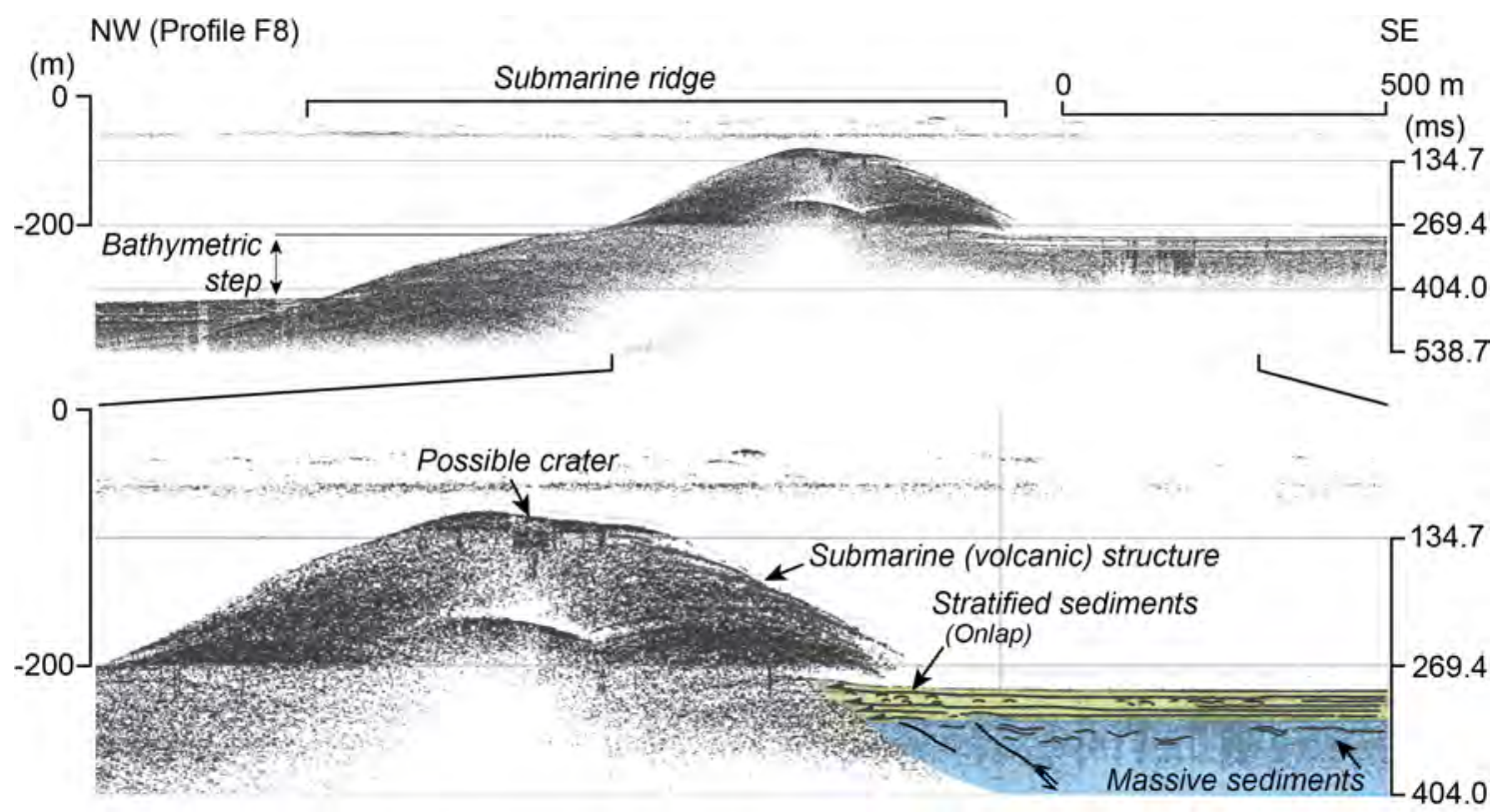

FIG. 5. Selected segment from sub-bottom profile F8 from the Aysén Fjord (location in Fig. 3), showing part of a submarine ridge located close to the Río Cuervo Fault (Fig. 6), which corresponds to the main structure of the Liquiñe-Ofqui Fault Zone in the area. This submarine ridge is associated with a bathymetric down step of $c a .100 \mathrm{~m}$ from the eastern part towards the western part of the fjord. It is interpreted as a submarine barrier, which in part limits the sedimentation of the most recent and wellstratified sediments constituting the Upper Unit of the sedimentary infill of the Aysén Fjord to the east (see text).

fine facies. Following sequential stratigraphy, we interpret that the sedimentation of the upper unit is probably associated to alternate supply of material from the marine basin and fluvial sediments from the Aysén River and other drainage systems in the area, most probably during the Holocene global high sea level stage since $7 \mathrm{cal}$. ka BP (Lambeck et al., 2002).

Fresh submarine fault scarps disrupting the sea bottom with vertical offsets of around 6-8 $\mathrm{m}$ were observed in subbottom profiles in the area of the 2007 seismic swarm in the Aysén Fjord (Fig. 4). Seismic profiles obtained from that area revealed strong deformation affecting sediments of the Upper and Lower seismic units (Fig. 4). This deformation is characterized by folded strata and loss of stratification, suggesting soft-sediment deformation which is particularly evident in the case of the Upper Unit. The area is affected and limited by faults with reverse slip component, which together with the deformed units define a positive flower structure (Fig. 4: Profiles F1 and F8). The most prominent fault, which is located at the SE border of this area, together with secondary faults defines a local pop-up structure at the sea floor, affecting both the upper and the lower units (Fig. 4). At its western margin, relatively higher complexity seems to be related to westward propagating low-angle thrust faults along the contact between the massive-to poorly laminatedLower Unit and the -well stratified- Upper Unit, as well as separating non-deformed and deformed sediments of this last unit (Fig. 4). Other minor scarps can also be observed in the middle of the rupture zone. The geometry of the entire submarine fault rupture zone defines a flower structure of $c a$. $2.5 \mathrm{~km}$ width measured along profile, with higher elevations at the SE and NW extremities (Fig. 4). The absence of any sedimentary layer covering fault scarps or disrupted sediments in this fjord, which is characterized by large supply of sediments from the Aysén River (Fig. 3), provides a strong argument to support that this submarine rupture zone is associated with very recent seismic events and possibly in part with the last seismic events, including the one of April 2007.

The sub-bottom profiles provide evidence of previous activities along faults affecting the sedimentary infill of the fjord (Fig. 5). In most of the cases, faults with reverse slip component affect the 
underlying poorly stratified sediments of the lower unit, but not the entire overlying stratified upper unit, suggesting previous seismic ruptures in the area (Fig. 5). Together with complementary bathymetric information from SHOA, the sub-bottom profile data shows a submarine ridge affected by faults and elongated in a SW-NE direction across the fjord in the area of the 2007 seismic swarm (Figs. 3 and 5; Profile F8). This ridge is associated with a bathymetric difference of about $100 \mathrm{~m}$ in the fjord bottom from $210 \mathrm{~m}$ to $310 \mathrm{~m}$ water depth from the eastern side towards its western side, respectively (Fig. 5). A submarine conic structure of about $130 \mathrm{~m}$ height that exhibits internal stratification and constitutes part of the ridge (Fig. 5) can be interpreted as a volcanic centre, following the inference of Lara (2009) from dark vesicular basalts dredged between fine sediments in the same area. The sub-bottom profile data show that the ridge constitutes the western limit for the upper stratified unit of the sedimentary infill in the fjord, and probably acts like a barrier for sediments supplied from the Aysén River.

\section{Fault cartography and kinematics}

Recent fault scarps and lineaments are largely disposed along N-S, SW-NE to SSW- NNE and E-W directions, which coincide with the more frequent directions of the valleys in the area, as in the case of the main lacustrine basins of Yulton and Meullín lakes (Fig. 6). Valleys oriented NW-SE are more frequent in the eastern part of the study area, which are generally affected by fault scarps and lineaments disposed along N-S, SW-NE and E-W directions. Besides, they also exhibit high degree of glacial erosion like U-shaped valleys and glacial striations (Fig. 7). Observations realized from outcrops located some kilometres to the east of Puerto Aysén evidenced outwash and fluvial sediments directly overlaid by volcanic ash fall deposits including buried soils at the base, from which we obtained calibrated radiocarbon ages of 10,350 and 12,000 cal. years BP (Table 1, Fig. 7). These results provide maximum ages for latest Pleistocene-Holocene development of fluvial sedimentary infill in the Aysén River valley, after the last ice sheet retreat in the area, which occurred shortly before $12 \mathrm{cal}$. ka BP.

The cartography of faults in the area, together with local observations from outcrops and kinematic indicators (Table 2), suggests dextral strike slip as the dominant mechanism for recent deformation, which dominates along the N-S and SW-NE oriented faults (Table 2; Fig. 6, Río Cuervo Fault, Punta Cola Fault) and locally along NNW-SSE directions, especially in the case of the north-eastern part of the study area (Table 2; Fig. 6, Los Palos Fault). Some east-west oriented faults exhibit kinematics indicators of sinistral strike slip mechanism (Table 2; Fig. 6). As shown in

TABLE 1. CONVENTIONAL AND CALIBRATED RADIOCARBON RESULTS (CAL. 0 BP = AD 1950).

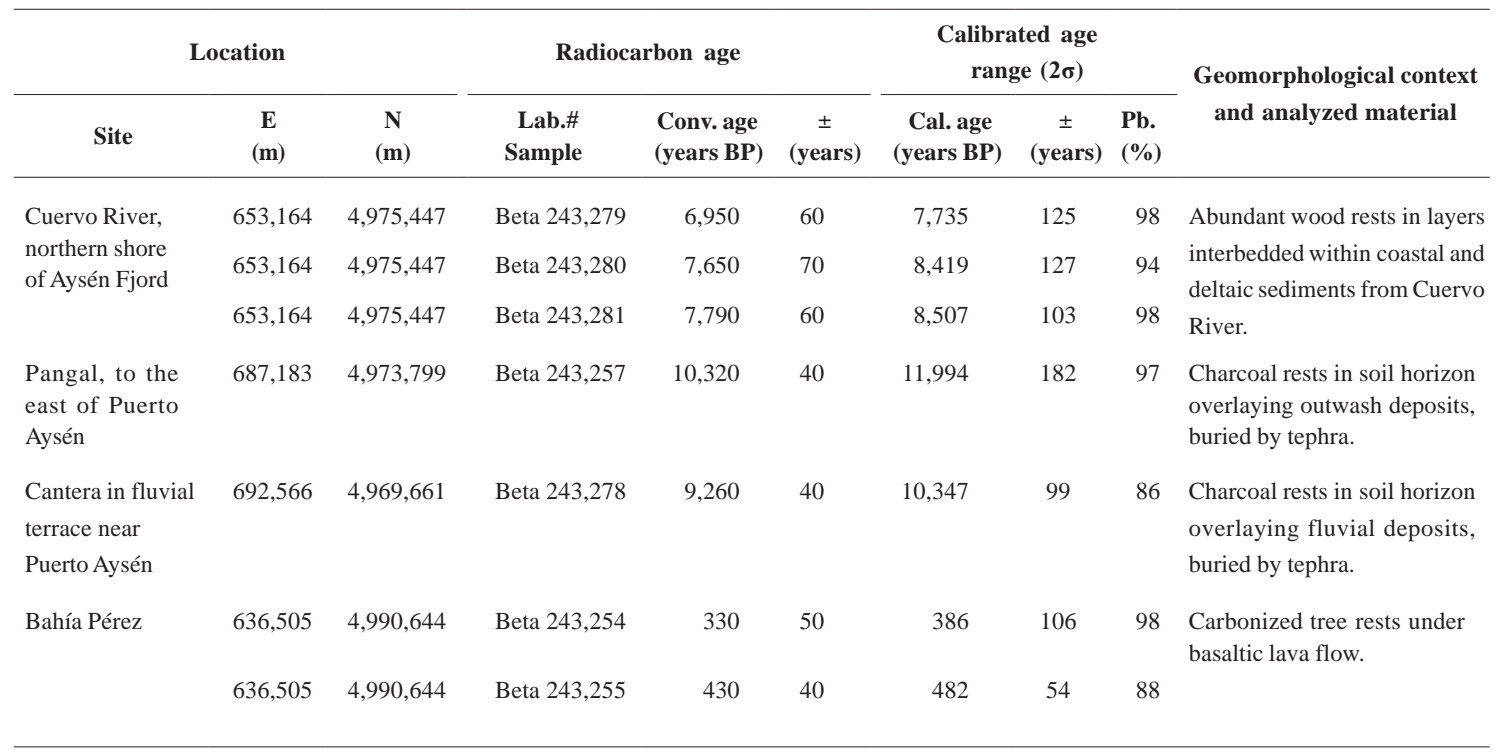


the geological maps (Fig.6), the major structures of the different systems displace each other. In some cases, EW-trending faults displace NS faults, which in turn displace or curve the EW faults. This would suggest that all structures are active and responding to the same stress state, possibly with differences of slip rate. In general, east-west oriented faults are deflected towards the south in the eastern blocks along north-south oriented fault systems, probably reflecting faster ate Quaternary slip rates along the later systems with respect to the first (Fig. 6). Additionally, a reverse component is associated with the dominantly dextral slip along N-S and NNW-SSE faults, while dextral-normal slip can be inferred from the fault geometry and from field observations along NE-SW fault planes (Fig. 6). According to the cartography, major structures have the segments as much as $40 \mathrm{~km}$ long, while secondary faults have those in the order of 10-20 km (Fig. 6).

The most prominent north-south fault is he Río Cuervo Fault (RCF), which can be characterized by fault segments up to 30-40 km long (Fig. 6). The main fault trace is located along the western side of Cuervo River valley, crossing the Aysén Fjord close to the location of the submarine ridge (Figs. 1, 5 and 6). This fault system can be correlated with a major north-south branch of the regional LOFZ (Hervé, 1994; Cembrano et al., 1996, 2002; Thompson, 2002; Fig. 6). Intense brittle shear deformation affecting granitoids along the RCF defines hundred metres width damage zones, visible from the Aysén Fjord (Table 2). Outcrops along this fault zone show subvertical faults dipping $60^{\circ}-90^{\circ} \mathrm{E}$, metric fault breccias, as well as $\mathrm{mm}$ to $\mathrm{cm}$ shear zones, with striations altogether with secondary minerals like iron oxides and incipiently chlorite and epidote in fault planes (Table 2).

The Punta Cola Fault (PCF) is a north-south striking $15-20 \mathrm{~km}$ long structure that crosses the Aysén Fjord about $5 \mathrm{~km}$ to the east of the RCF (Figs. 6 and 8). Rocks affected by intense brittle deformation including fault planes and fractures, breccia and centimetre shear zones were observed along the several hundred metres width damage zones at the northern side of the fjord (Fig. 8; Table 2). The location of the major Mw 6.2 April 2007 earthquake given by the local seismic network (GUC, 2007; Legrand et al., 2011; Figs. 1 and 3), coincides with the location of this north-south fault (Fig. 6), and with the location of the submarine rupture observed in sub-bottom profiles (Fig. 4). Large landslides triggered by this main shock occurred close to this fault in the fjord on 2007 (Fig. 2). In particular, the largest landslide that occurred in the ravine next to Punta Cola (Clavero et al., 2008; Naranjo et al., 2009; Sepúlveda and Serey, 2009; Sepúlveda et al., 2010), was limited on its eastern side by north-south $80-85^{\circ} \mathrm{W}$ dipping faults associated with the PCF (Figs. 6 and 8).

Sub-bottom profiles and surface features indicate that several SW-NE striking secondary faults, with segments up to $10 \mathrm{~km}$ in length, are located between the RCF and the PCF (Fig. 6). Besides, deformed submarine sediments and/or surface manifestations of postglacial fault activity were observed in seismic profiles from the fjord bottom, that we associate with SW-NE structures traversing the fjord between the RCF and PCF (Fig. 6). This area corresponds to the zone where the epicentres of hundreds of seismic events $(\mathrm{Mw} \leq 3.0)$ associated with the last seismic swarm were localized (GUC, 2007; Legrand et al., 2011; Fig. 3). In the area of the RCF deltaic sediments from the Cuervo River are interbedded with coastal marine sediments and form a terrace located up to 8-10 $\mathrm{m}$ above the fjord sea level. AMS radiocarbon results from levels with abundant tree remnants provided calibrated ages between 7750 and 8500 cal. years BP (Table 1; Fig. 9). This suggests several metres of surface uplift since the early Holocene (Fig. 9). These sediments are affected by NE-striking faults and are overlain by gravel deposits, suggesting previous surface seismic rupture associated with secondary faults between the RCF and PCF (Table 2; Fig. 9).

Two other north-south fault systems are the Punta Mano-Lago Yulton Fault (PMLYF) and Los Palos Fault, near Puerto Aysén (LPF; Fig. 6). Outcrops from LPF show fault breccias and $\mathrm{mm}$ to $\mathrm{cm}$ shear zones associated with subvertical N-S and NNWSSE fault planes dipping $50-80^{\circ}$, with striations and secondary minerals evidencing dominant dextral strike slip mechanism (Table 2; Fig. 10). In the area of Puerto Aysén, a fluvial terrace of the Aysén River occurs up to 8-10 m over the thalweg of the river. In this area the altitude of the Puerto Aysén fluvial terrace increases downstream from the east towards the centre of the city, suggesting a tectonic control in its geometry that, besides fluvial dynamics, could be associated to recent activity of Los Palos Fault. Sub-bottom profile data from the Riesco Lake, which is located $6 \mathrm{~km}$ to the south of Puerto Aysén, evidenced recent deformation 

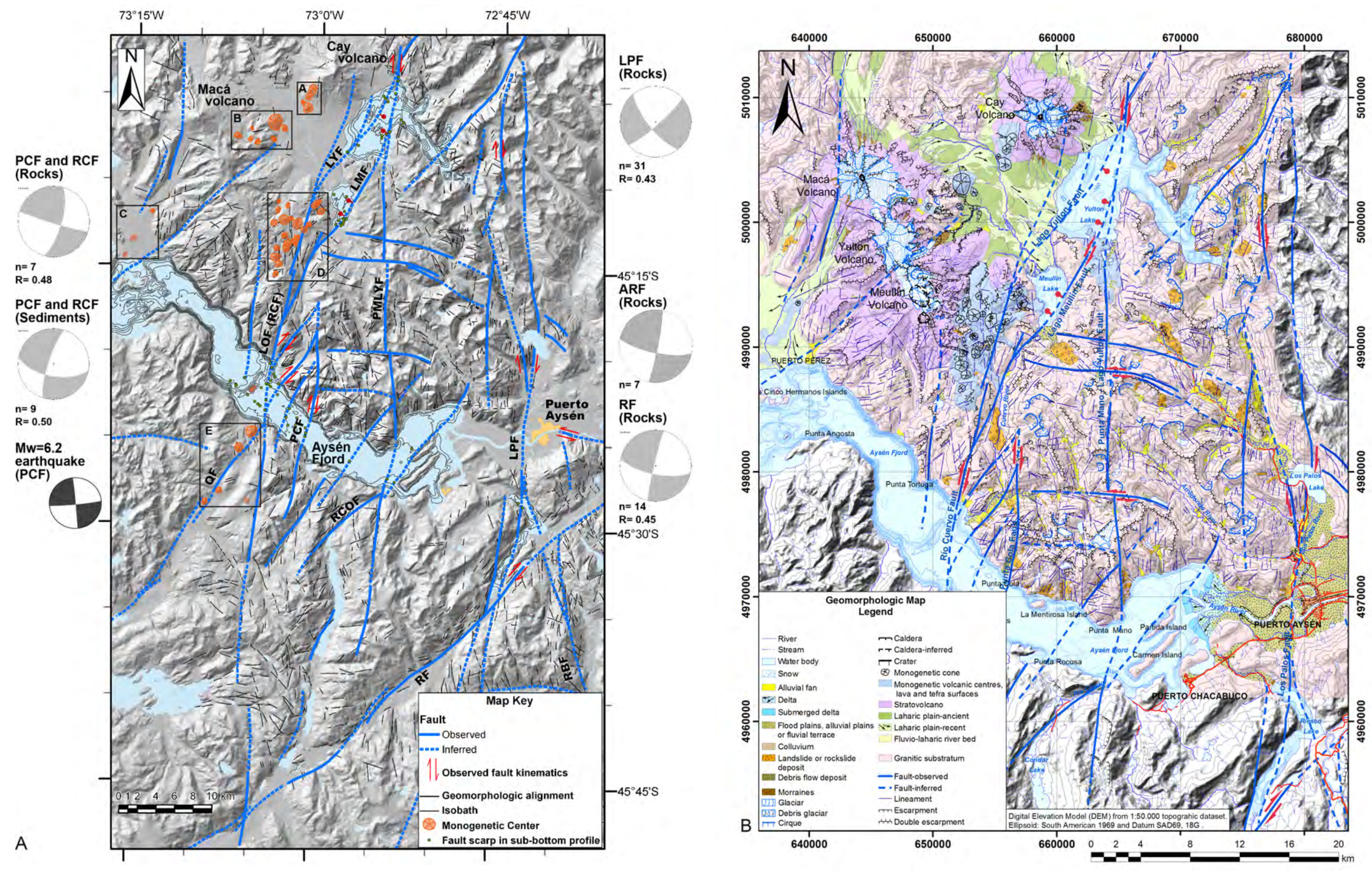

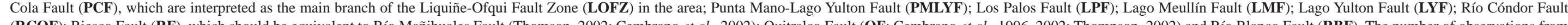

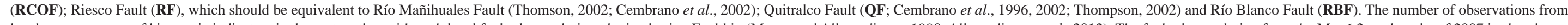

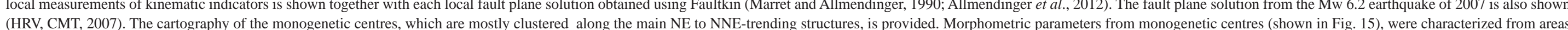
A, B, C, D and E, which correspond to Cay, Macá, Bahía Pérez, Meullín and Pescado River zones, respectively. B. Geomorphologic chart of the study area located to the north of the Aysén Fjord. 


\section{Cantera E Puerto Aysén}

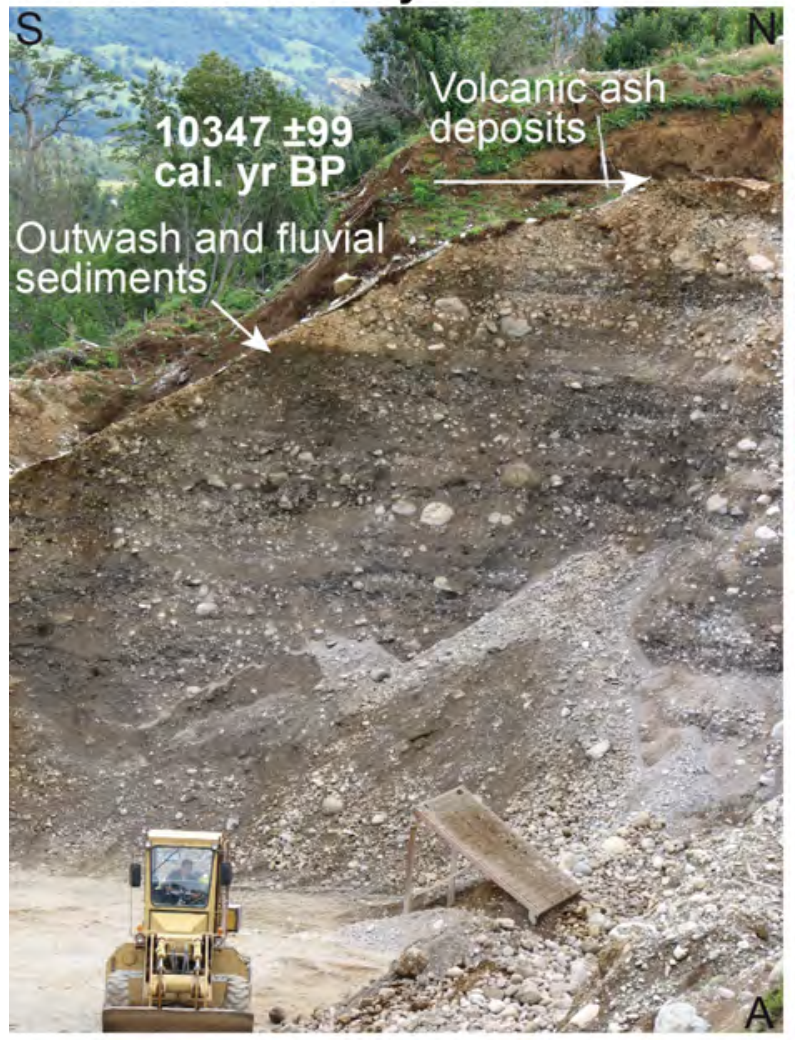

\section{Pangal (E Puerto Aysén)}
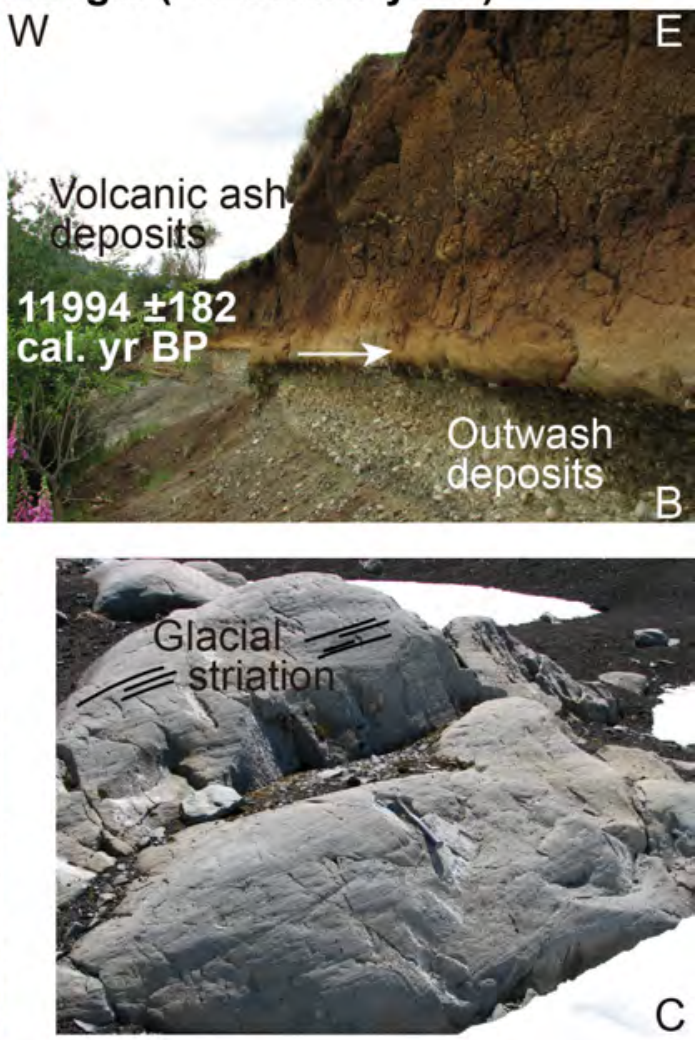

FIG. 7. A, B. Outcrops showing outwash and fluvial sediments directly overlaid by volcanic ash fall deposits, located some kilometres to the east of Puerto Aysén, and calibrated radiocarbon results from buried soils (Table 1); C. Glacial striations affecting bedrocks in the study region. These observations point to a last Pleistocene ice sheet retreat before 12,000 cal. years BP in the area.

affecting postglacial massive -probably sandy fluvial dominated- sediments of this lacustrine basin, dammed by Pleistocene moraines to the west. This deformation can be related with a reverse slip component along a north-south dextral fault segment of LPF (Fig. 11), which supports the active character of this fault system.

A major SW-NE striking fault system is located in the southern part of the area, which is the Riesco Fault (RF, Fig. 6). This last fault (RF) coincides with the main NE-SW branch of the LOFZ, which has been named Mañihuales Fault to the northeast of the study area (Thompson, 2002; Cembrano et al., 2002). Results from SPOT satellite imagery may be interpreted as showing systematic rightlateral displacement of recent drain-age systems along the RF (Fig. 12), which could be taken as preliminary evidence for Holocene strike slip deformation along the LOFZ in the area. Local outcrops along this fault system reveal subvertical fault planes with $\mathrm{mm}$ to $\mathrm{cm}$ shear zones, together with striations and secondary minerals in fault planes evidencing dominant dextral strike slip fault kinematics associated with structures oriented N-S to NNE-SSW (Table 2; Fig. 12).

Another NE-SW main branch of the LOFZ in the region is the Quitralco Fault (QF; Cembrano et al., 1996, 2002; Thompson, 2002). This fault system joints the RCF on the southern shore of the fjord 2-3 km to the SE of the submarine ridge observed in sub-bottom profiles, within an area where several monogenetic volcanic centres are located (Fig. 6).

\section{Monogenetic volcanic centres}

The geological analysis revealed that dozens of well preserved monogenetic volcanic centres 
TABLE 2. LOCAL FAULT DATA FROM SELECTED OUTCROPS.

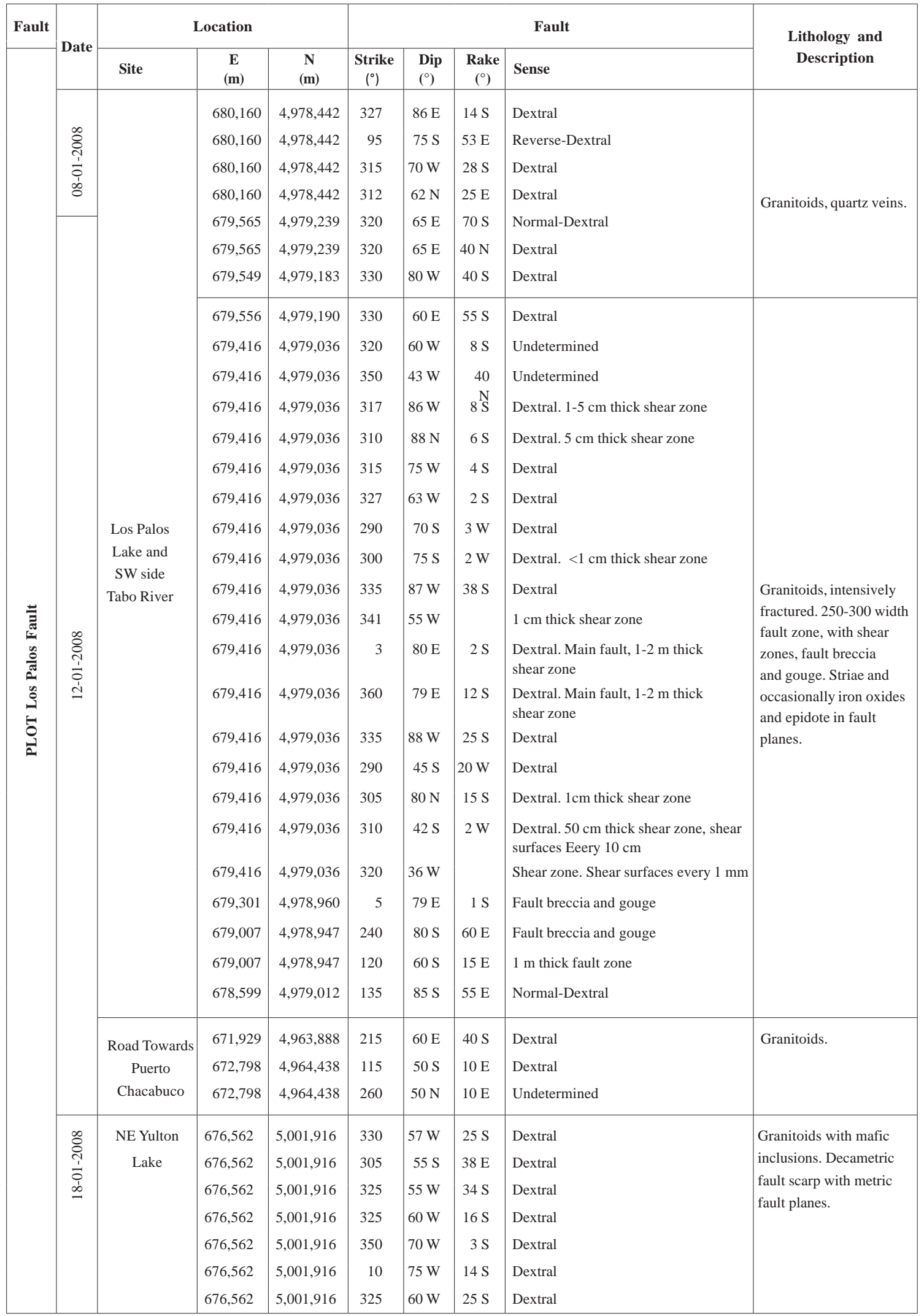


Table 2 continued.

\begin{tabular}{|c|c|c|c|c|c|c|c|c|c|}
\hline Fault & \multirow{2}{*}{ Date } & \multicolumn{3}{|c|}{ Location } & \multicolumn{4}{|c|}{ Fault } & \multirow{2}{*}{$\begin{array}{l}\text { Lithology and } \\
\text { Description }\end{array}$} \\
\hline \multirow{4}{*}{ 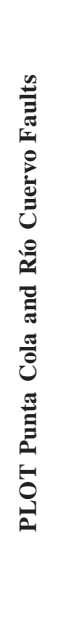 } & & Site & $\mathrm{E}(\mathrm{m})$ & $\mathbf{N}(\mathbf{m})$ & $\begin{array}{c}\text { Strike } \\
\left({ }^{\circ}\right)\end{array}$ & $\begin{array}{l}\text { Dip } \\
\left({ }^{\circ}\right)\end{array}$ & $\begin{array}{l}\text { Rake } \\
\left({ }^{\circ}\right)\end{array}$ & Sense & \\
\hline & $\begin{array}{l}\infty \\
\stackrel{0}{1} \\
\text { 1. } \\
0 \\
0 \\
0\end{array}$ & $\begin{array}{l}\text { Cuervo River, } \\
\text { W side in } \\
\text { front of } \\
\text { Marta River }\end{array}$ & $\begin{array}{l}654,591 \\
654,591 \\
654,591 \\
654,591\end{array}$ & $\begin{array}{r}4,978,733 \\
4,978,733 \\
4,978,733 \\
4,978,733\end{array}$ & $\begin{array}{r}221 \\
9 \\
350 \\
350\end{array}$ & $\begin{array}{r}79 \mathrm{E} \\
89 \mathrm{E} \\
15 \mathrm{E} \\
15 \mathrm{E}\end{array}$ & $\begin{array}{r}6 \mathrm{~S} \\
20 \mathrm{~S} \\
80 \mathrm{~N} \\
20 \mathrm{~N}\end{array}$ & $\begin{array}{l}\text { Undetermined } \\
\text { Dextral } \\
\text { Undetermined } \\
\text { Undetermined }\end{array}$ & $\begin{array}{l}\text { Granitoids, intensively fractured. } \\
>200 \text { m width fault zone. Fault } \\
\text { planes limit landslide deposit. }\end{array}$ \\
\hline & 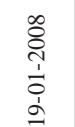 & N Yulton Lake & $\begin{array}{l}665,015 \\
665,015\end{array}$ & $\begin{array}{l}5,013,070 \\
5,013,070\end{array}$ & $\begin{array}{l}355 \\
340\end{array}$ & $\begin{array}{l}62 \mathrm{E} \\
88 \mathrm{E}\end{array}$ & $\begin{array}{r}65 \mathrm{~N} \\
64 \mathrm{~S}\end{array}$ & $\begin{array}{l}\text { Reverse-Dextral. } \\
1 \mathrm{~cm} \text { thick shear zone } \\
\text { Normal-Dextral }\end{array}$ & $\begin{array}{l}\text { Granitoids, intensively fractured. } \\
1 \mathrm{~cm} \text { thick shear zone. Striae and } \\
\text { epidote in fault planes. }\end{array}$ \\
\hline & \begin{tabular}{l}
$\infty$ \\
0 \\
$\stackrel{N}{1}$ \\
1 \\
0 \\
0 \\
\hdashline \\
$\rightarrow$
\end{tabular} & $\begin{array}{l}\text { N shore } \\
\text { Aysén Fjord. } \\
\text { Quebrada near } \\
\text { Punta Cola }\end{array}$ & $\begin{array}{l}656,374 \\
656,374 \\
656,374 \\
656,374\end{array}$ & $\begin{array}{r}4,972,832 \\
4,972,832 \\
4,972,832 \\
4,972,832\end{array}$ & $\begin{array}{r}15 \\
271 \\
270 \\
30\end{array}$ & $\begin{array}{l}85 \mathrm{~W} \\
75 \mathrm{~N} \\
67 \mathrm{~N} \\
80 \mathrm{E}\end{array}$ & $\begin{array}{l}25 \mathrm{~S} \\
27 \mathrm{E} \\
31 \mathrm{E} \\
12 \mathrm{~S}\end{array}$ & $\begin{array}{l}\text { Dextral } \\
\text { Sinistral } \\
\text { Sinistral } \\
\text { Dextral }\end{array}$ & $\begin{array}{l}\text { Granitoids, mafic inclusions, } \\
\text { intensively fractured. }>200 \mathrm{~m} \text { width } \\
\text { fault zone, with shear zones, breccia } \\
\text { and gouge.Large landslide limited } \\
\text { by ca. N-S and E-W striking faults. }\end{array}$ \\
\hline 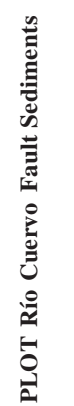 & 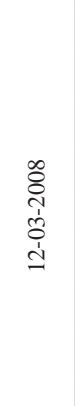 & $\begin{array}{l}\mathrm{N} \text { shore Aysén } \\
\text { Fjord. Cuervo } \\
\text { River }\end{array}$ & $\begin{array}{l}653,180 \\
653,180 \\
653,180 \\
653,180 \\
653,180 \\
653,180 \\
653,180 \\
653,180 \\
653,180\end{array}$ & $\begin{array}{l}4,975,422 \\
4,975,422 \\
4,975,422 \\
4,975,422 \\
4,975,422 \\
4,9754,22 \\
4,975,422 \\
4,975,422 \\
4,975,422\end{array}$ & $\begin{array}{r}23 \\
12 \\
4 \\
14 \\
20 \\
348 \\
354 \\
60 \\
50\end{array}$ & $\begin{array}{l}73 \mathrm{~W} \\
88 \mathrm{E} \\
68 \mathrm{~W} \\
70 \mathrm{~W} \\
88 \mathrm{~W} \\
62 \mathrm{~W} \\
77 \mathrm{~W} \\
88 \mathrm{~N} \\
85 \mathrm{~S}\end{array}$ & $\begin{array}{l}24 \mathrm{~S} \\
24 \mathrm{~S} \\
24 \mathrm{~S} \\
30 \mathrm{~S} \\
30 \mathrm{~S} \\
24 \mathrm{~S} \\
24 \mathrm{~S} \\
30 \mathrm{~S} \\
30 \mathrm{~S}\end{array}$ & $\begin{array}{l}\text { Dextral } \\
\text { Dextral } \\
\text { Dextral } \\
\text { Dextral } \\
\text { Dextral } \\
\text { Dextral } \\
\text { Dextral } \\
\text { Dextral } \\
\text { Dextral }\end{array}$ & $\begin{array}{l}\text { Sediments. Fault planes with striae, } \\
\text { affecting deltaic sediments from the } \\
\text { Cuervo River. }\end{array}$ \\
\hline 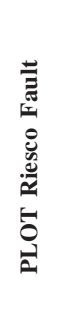 & $\begin{array}{l}\infty \\
\stackrel{人}{1} \\
1 \\
0 \\
0 \\
0 \\
0\end{array}$ & $\begin{array}{l}\text { Baja and } \\
\text { Alta Lakes }\end{array}$ & $\begin{array}{l}678,176 \\
678,176 \\
677,693 \\
677,693 \\
677,693 \\
677,693 \\
677,483\end{array}$ & $\begin{array}{l}4,954,831 \\
4,954,831 \\
4,954,651 \\
4,954,651 \\
4,954,651 \\
4,954,651 \\
4,954,931\end{array}$ & $\begin{array}{l}26 \\
55 \\
14 \\
45 \\
40 \\
43 \\
34\end{array}$ & $\begin{array}{l}84 \mathrm{E} \\
50 \mathrm{~N} \\
78 \mathrm{~W} \\
83 \mathrm{~N} \\
73 \mathrm{E} \\
76 \mathrm{E} \\
41 \mathrm{~W}\end{array}$ & $\begin{array}{r}33 \mathrm{~S} \\
18 \mathrm{~W} \\
27 \mathrm{~S} \\
85 \mathrm{E} \\
83 \mathrm{~S} \\
65 \mathrm{~S} \\
25 \mathrm{~S}\end{array}$ & $\begin{array}{l}\text { Dextral } \\
\text { Dextral } \\
\text { Dextral } \\
\text { Normal-Dextral } \\
\text { Normal-Dextral } \\
\text { Normal-Dextral } \\
\text { Dextral }\end{array}$ & $\begin{array}{l}\text { Granitoids with mafic inclusions. } \\
\text { Fault planes with striae and } \\
\text { occasionally with iron oxides and } \\
\text { epidote. }\end{array}$ \\
\hline 三 & $\begin{array}{l}\infty \\
\stackrel{1}{1} \\
\grave{1} \\
\vdots \\
\vdots \\
0\end{array}$ & $\begin{array}{l}\text { S Aysén } \\
\text { River }\end{array}$ & $\begin{array}{l}683,867 \\
683,867\end{array}$ & $\begin{array}{l}4,969,418 \\
4,969,418\end{array}$ & $\begin{array}{l}275 \\
288\end{array}$ & $\begin{array}{l}86 \mathrm{~N} \\
60 \mathrm{~S}\end{array}$ & $\begin{array}{l}21 \mathrm{E} \\
18 \mathrm{E}\end{array}$ & $\begin{array}{l}\text { Sinistral } \\
\text { Sinistral }\end{array}$ & $\begin{array}{l}\text { Granitoids. E-W fault planes limit } \\
\text { landslide escarpments. }\end{array}$ \\
\hline 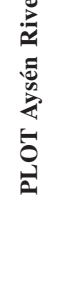 & 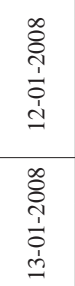 & $\begin{array}{l}\text { S Aysén River, } \\
\text { close to the } \\
\text { Blanco River }\end{array}$ & $\begin{array}{l}687,391 \\
687,391 \\
687,391 \\
683,890 \\
688,545\end{array}$ & $\begin{array}{l}4,968,069 \\
4,968,069 \\
4,968,069 \\
4,969,433 \\
4,967,431\end{array}$ & $\begin{array}{r}2 \\
10 \\
10 \\
290 \\
345\end{array}$ & $\begin{array}{l}67 \mathrm{E} \\
87 \mathrm{~W} \\
75 \mathrm{~W} \\
70 \mathrm{~S} \\
49 \mathrm{E}\end{array}$ & $\begin{array}{r}55 \mathrm{~S} \\
8 \mathrm{~S} \\
8 \mathrm{~S} \\
20 \mathrm{E} \\
11 \mathrm{~S}\end{array}$ & $\begin{array}{l}\text { Normal-Dextral } \\
\text { Dextral } \\
\text { Dextral } \\
\text { Sinistral } \\
\text { Dextral }\end{array}$ & $\begin{array}{l}\text { Granitoids. Decametric escarpment } \\
\text { oriented close to N-S direction, with } \\
\text { lanslides at the foot. }\end{array}$ \\
\hline
\end{tabular}




\section{Río Cuervo and Punta Cola Faults}
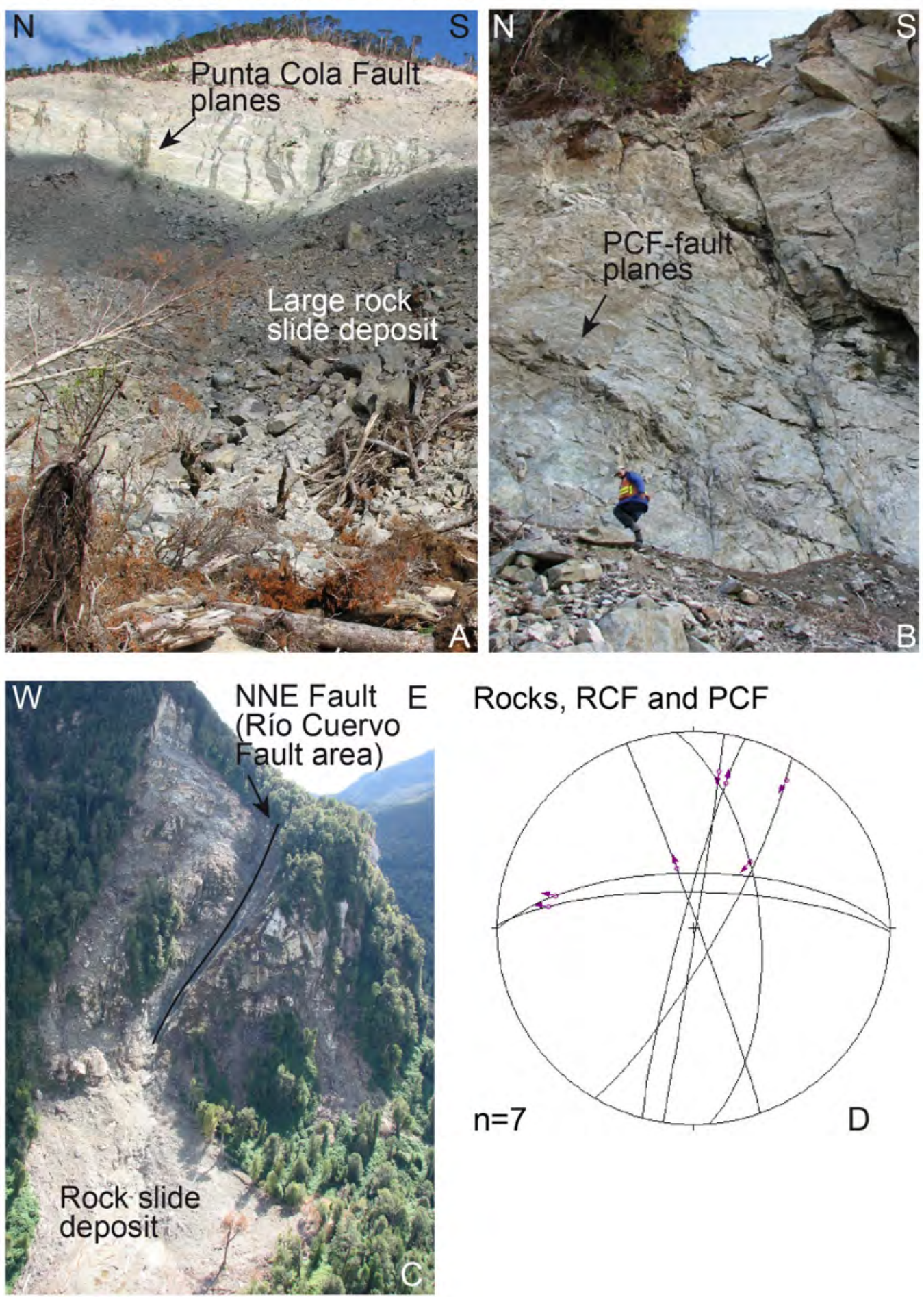

Rocks, RCF and PCF

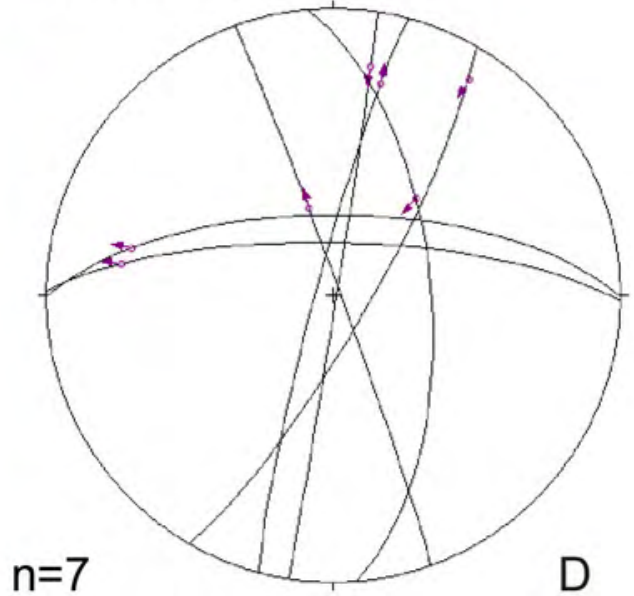

FIG. 8. Photographs showing outcrops associated to Punta Cola and Río Cuervo faults, to the north of the Aysén Fjord (Fig. 6a). A, B. North-south fault planes and fault scarps limiting a large rockslide deposit formed during the last Mw 6.2 earthquake along the area of the Punta Cola Fault; C. Rockslide deposit associated to a NNE-striking fault in the area of the Río Cuervo Fault; D. Local kinematic observations from fault planes of the RCF and PCF (Table 2). 


\section{Río Cuervo Fault area}
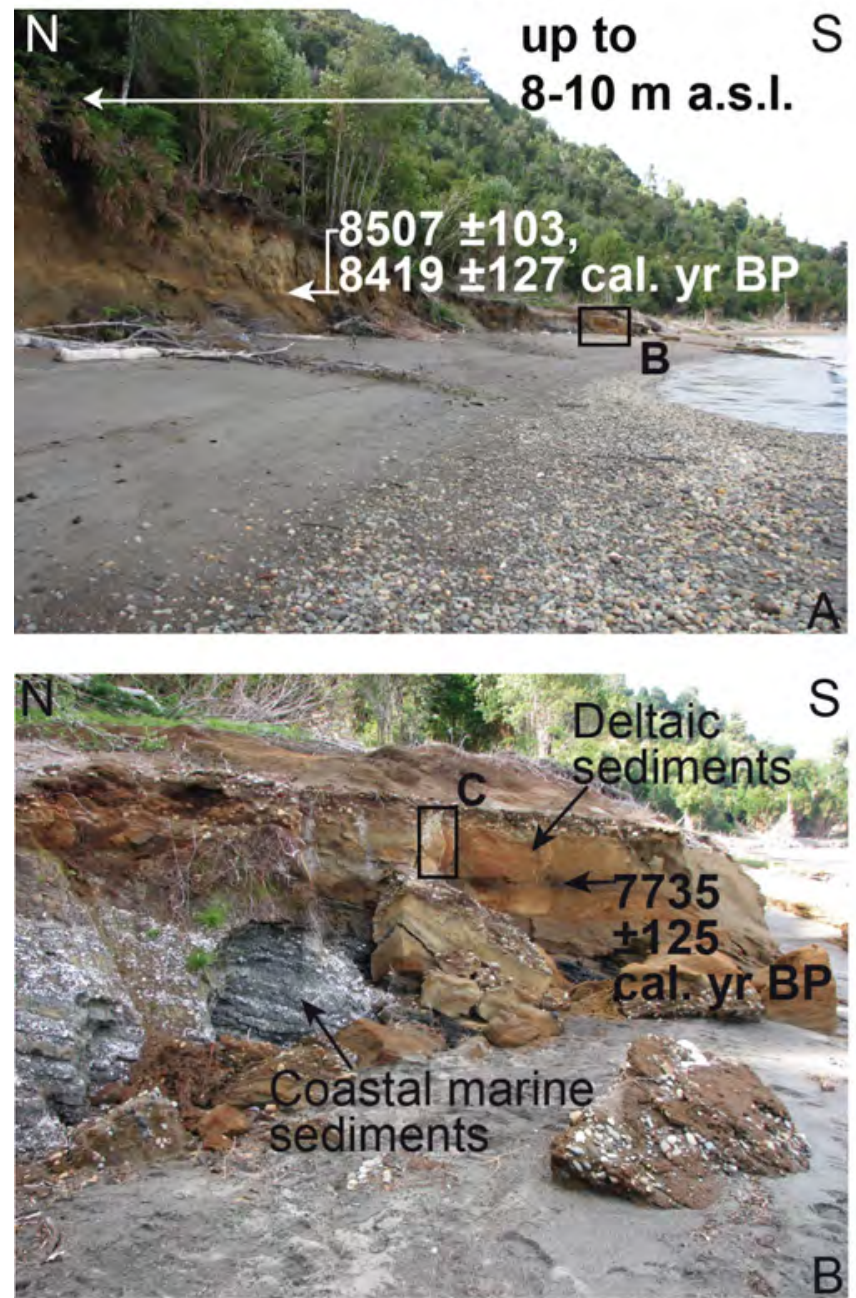

\section{Sediments, RCF area}
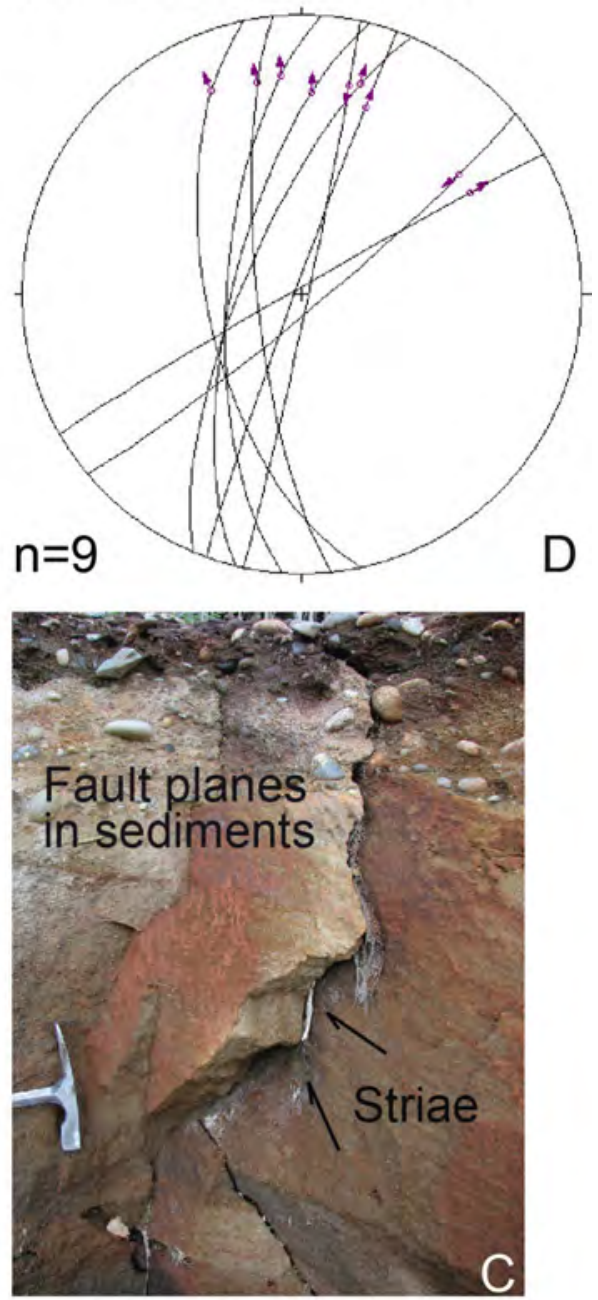

FIG. 9. Holocene littoral and deltaic sediments from the Cuervo River affected by faults on the northern shore of the Aysén Fjord. A, B and C. Views showing deltaic sediments (A, B), affected by faults (C), in the area of the Río Cuervo Fault (RCF), and calibrated radiocarbon results (Table 1). D. Local kinematic data from faults affecting sediments in the area of the RCF (Table 2).

are clustered along main faults oriented following NE-SW, NNE-SSW and N-S directions (Fig. 6). A number of monogenetic volcanic centres are located close to the Pleistocene-Holocene basaltic to dacitic Macá and Cay stratovolcanoes (Stern et al., 1976; López et al., 1993; D’Orazio et al., 2003), some of them constituting possible parasite structures of the former volcano. Other monogenetic volcanic centres are located in the area of the Cuervo River close to the Meullín Lake and on the southern shore of the Aysén Fjord along the Pescado River valley (Demant et al., 1994; Lahsen et al., 1997; Fig. 13). Minor eruptive centres are characterized by hundreds of metres high conic structures with diameter up to $c a .2$ $\mathrm{km}$. Most of them are elongated and exhibit variable degree of erosion and vegetation cover, suggesting that eruptive activities occurred throughout the Holocene period. The most recent minor volcanic centres are located in the western part of the study area, at Bahía Pérez (Puerto Pérez area; Fig. 6), southwest of the Macá Volcano (Fig. 13a-d). Radiocarbon data from carbonized tree remnants under a basaltic lava flow from one of these centres yielded ages of $386 \pm 106$ and $482 \pm 54$ cal. yr BP, which means that this centre erupted between the years AD 1450 and 1670, indicating its historical age (Table 1, Figs. 13c 


\section{Los Palos Fault}
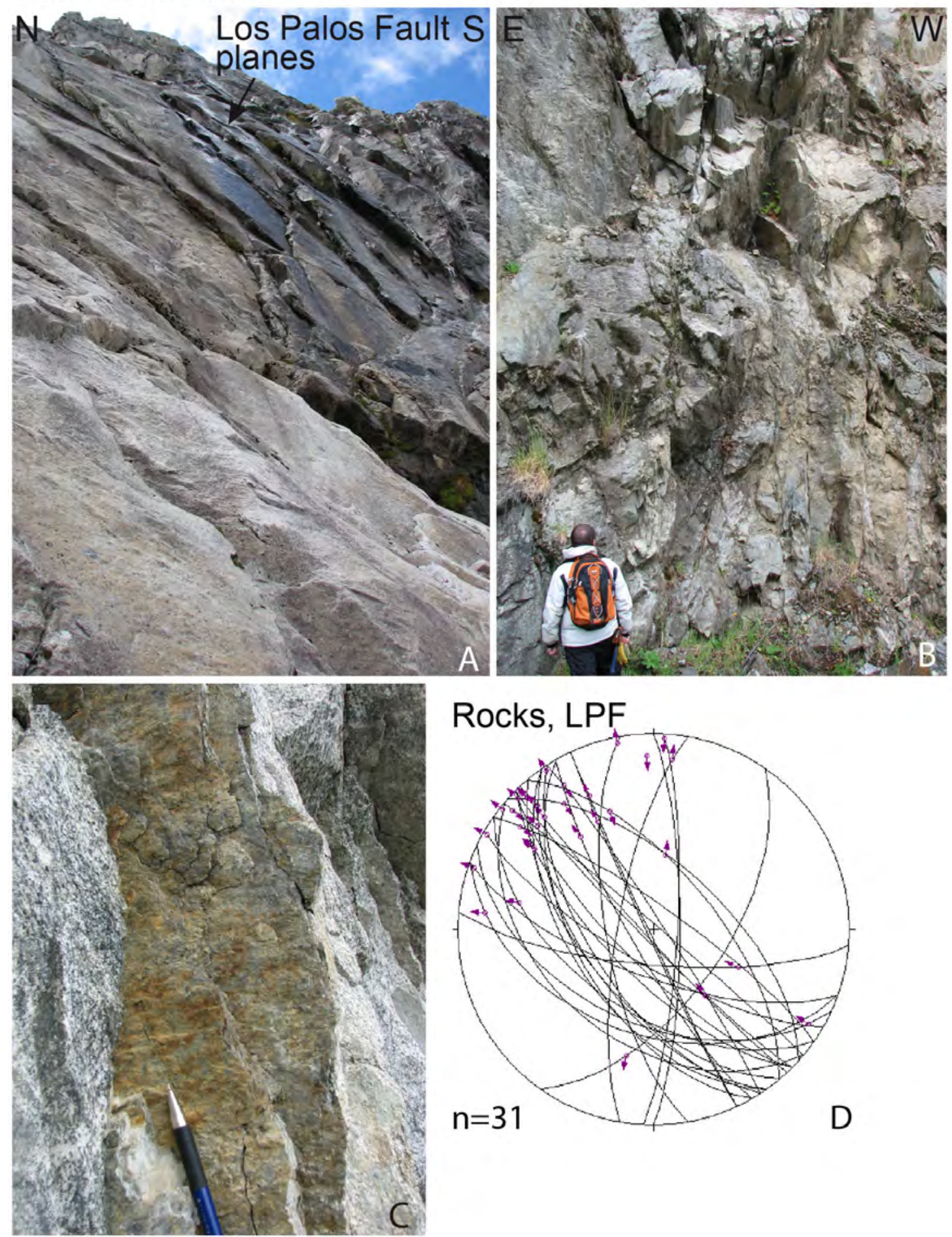

FIG. 10. Los Palos Fault (LPF) outcrops showing metric-scale fault planes (A. northeastern area of the Yulton Lake basin), breccias and shear zones affecting granitoids (B. and C. southern shore of Los Palos Lake), and local kinematics data (D. composite from both sites, Table 2). 
(m) NW (Profile R1)
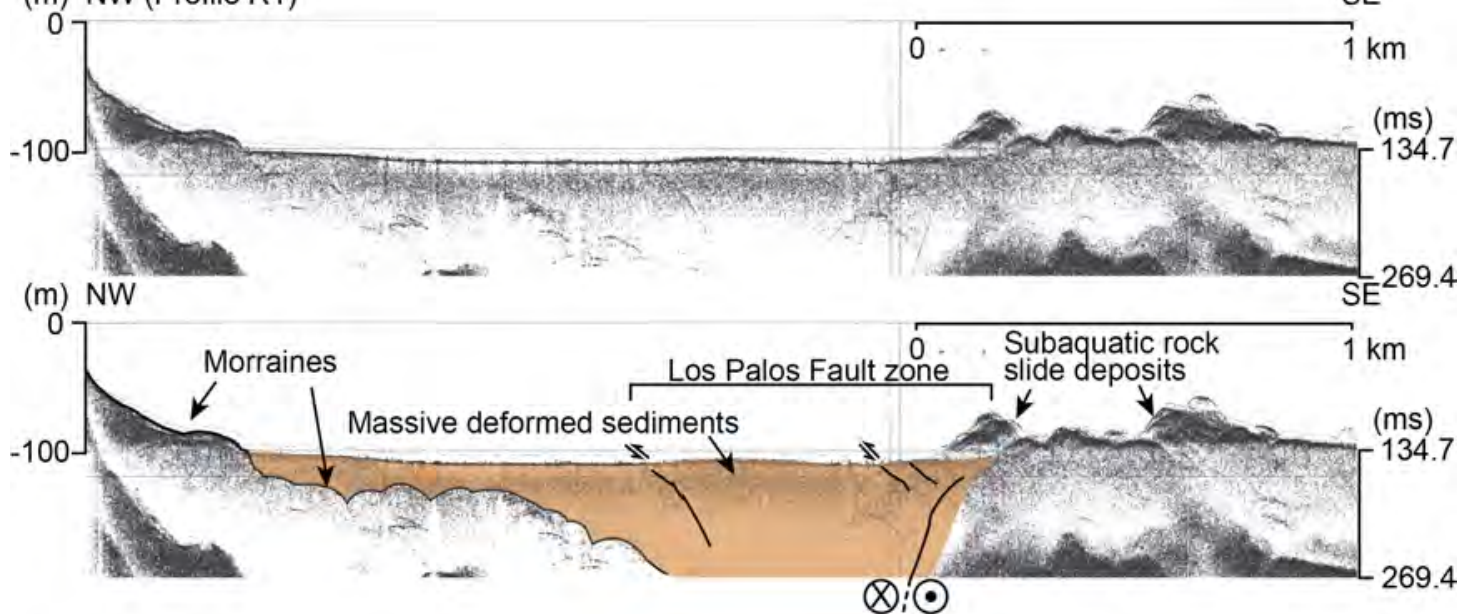

FIG. 11. Sub-bottom profile from the Riesco Lake showing evidences of recent (postglacial) deformation affecting massive sandy fluvial and lacustrine sediments along Los Palos Fault system (LPF; location in figure 3).

\section{Riesco Fault}
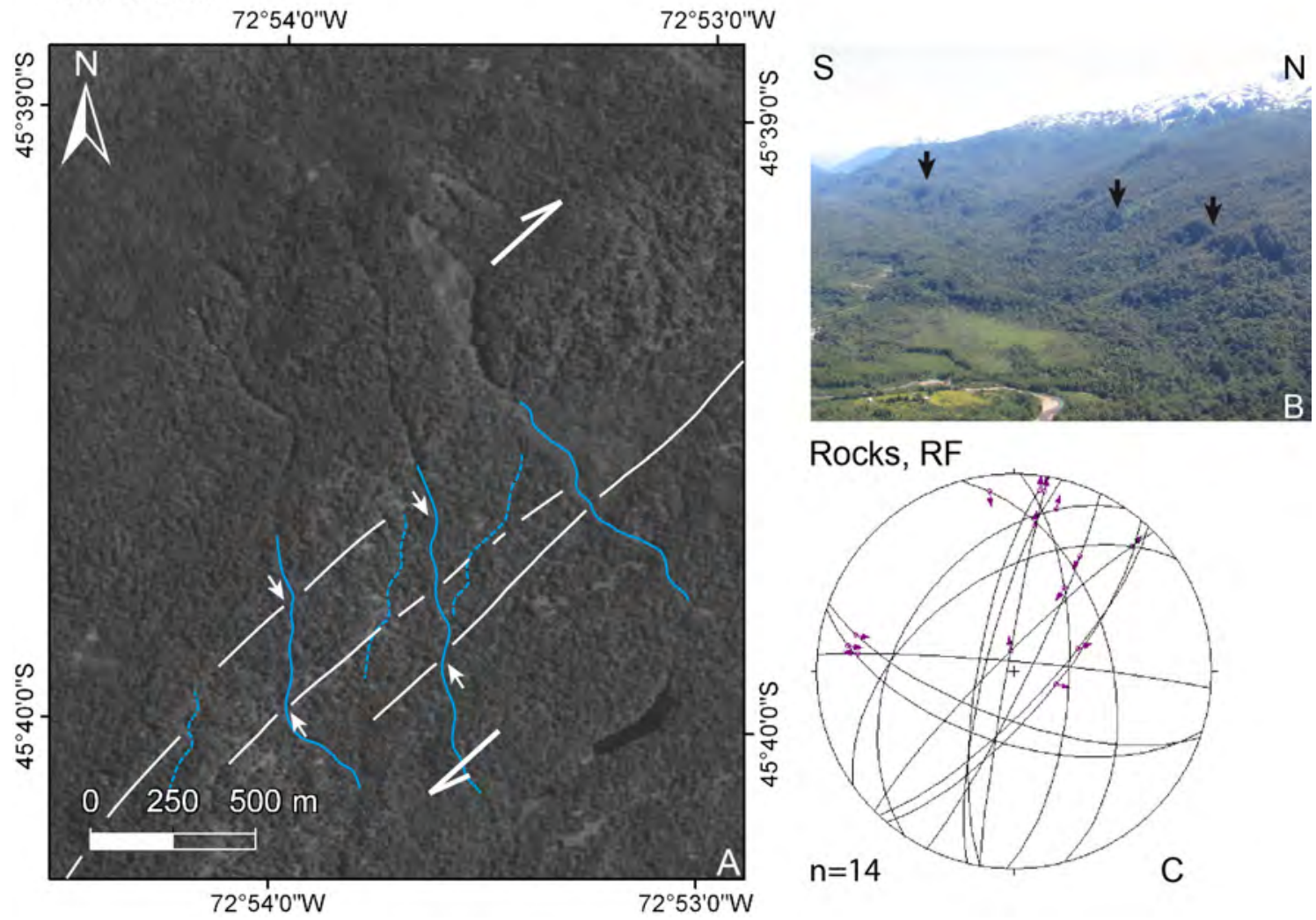

FIG. 12. SPOT satellite image from the area of the Riesco Fault (RF) showing systematic right-lateral deflection of drainage systems which could reflects Holocene dextral strike slip (A), fault scarps (B) and kinematics data (C). White and black arrows indicate probably dextral strike-slip displacement of drainages (blue) and fault scarps, respectively. Segmented blue lines represent abandonment drainages. 
and d). Among the most vegetated features are the monogenetic centres located at Pescado River on the southern shore of the Aysén Fjord close to the RCF, and to the south of the submarine ridge. This area is characterized by major north-south oriented escarpments and lineaments that we interpret as the continuation of the dextral Río Cuervo Fault system towards the south of the fjord, with associated secondary NE-SW faults inferred from SPOT satellite imagery (Figs. 13e and f).

The geomorphological analysis of the minor volcanic centres confirmed that the orientations of the major axes of the monogenetic cones coincide with those of the master faults of the LOFZ, with preferential strikes of NNE to NE (Figs. 14 and 15). Nonetheless, within each monogenetic group clustered in different areas it is possible to find several orientations, suggesting a local association with the faults. The degree of ellipticity of the monogenetic cones is moderate according to Tibaldi (1995), with an average ratio of minimum to maximum axis length of $0.80 \pm 0.13$. The strongest ellipticity is detected in a monogenetic cone of the Meullín group close to the RCF system, with a ratio of 0.45 , although in this zone there is a great dispersion ranging from circular to elongated cones (Fig. 14). As a group, the parasitic cones of Macá volcano have the higher average ellipticity with a degree of $0.71 \pm 0.10$, while the others vary between 0.81 and 0.85 (Figs. 6 and 15).

The sub-bottom profiles, together with bathymetric information from the Aysén Fjord, show that the submarine ridge is elongated in a NE-SW direction and that is located close to the junction of the NE-striking Quitralco Fault (QF) and the north-south-striking RCF (Figs. 5 and 6). The stratified conic structure forming part of this ridge is also elongated in a NESW direction, and is characterized by a diameter of more than $500 \mathrm{~m}$ and a height exceeding $100 \mathrm{~m}$ from its base at the eastern side of the ridge, reaching minimum water depths in the order of 60-70 $\mathrm{m}$ b.s.l. (Fig. 5). The internal stratification and the dimension of this submarine structure forming part of the ridge is similar to other volcanic monogenetic centres in the area, like those located at Pescado River (Figs. 5 and 13e and f), which supports the interpretation of its volcanic origin.

Sub-bottom profile and bathymetric data obtained from the north-eastern side of the Yulton Lake revealed a conic structure that may be interpreted as a subaquatic volcanic centre located at the base of the Cay volcano (Fig. 16). In fact, this is a conic structure elongated in a SW-NE direction, which exhibits internal stratification that suggests a volcanic origin under shallow subaquatic conditions (Fig. 16). On its south-eastern border, this feature is affected by faults with normal slip component suggesting postglacial deformation under local extensional regime, which can be related to the SW-NE-striking Lago Yulton Fault (LYF; Figs. 6 and 16), inferred from bathymetric,sub-bottom profile data and local field observations on the northern shore of the Yulton Lake (Fig. 6; Table 2). Faults with reverse slip component were deduced from fault scarps disrupting the lake bottom on the north western border of this feature that can be associated to north-south striking faults interpreted from sub-bottom profiles and bathymetric information. Such an interpretation is consistent with fault kinematics deduced from the fault cartography, locally supported by kinematic indicators from the entire study area and especially from the northern shore of the Yulton Lake (Figs. 6 and 16).

\section{Discussion}

The cartography of active faults indicates that recent deformation in the area occurs mainly along dextral N-S and NE-SW faults. E-W striking faults accommodate sinistral strike slip. The geological evidences show local reverse slip component associated with N-S and locally NNW-striking faults, which favours the generation of pop-up structures, as suggested by submarine evidences of the last seismic ruptures in the Aysén Fjord bottom, as well as by topographic and structural data (Fig. 6). According to the fault cartography and local field data, NESW secondary faults accommodate dextral-normal slip. We interpret that the activity of the main N-S faults together with NE-SW faults (Fig. 16), would have favored the development of extensional duplex structures which together with strong glacial erosion have driven the formation of the Yulton and Meullín lake basins.

Additionally, local kinematics deduced from striations returned $\mathrm{R}$ values in the order of 0.43 0.50 (Table 2; Fig. 6), where $\mathrm{R}=\left(\mathrm{e}_{2}-\mathrm{e}_{3}\right) /\left(\mathrm{e}_{1}-\mathrm{e}_{3}\right)$, and $\mathrm{e}_{3}, \mathrm{e}_{2}$ and $\mathrm{e}_{1}$ correspond to shortening (P), intermediate (B) and extension (T) axes, respectively, suggesting dominant plain strain along faults. The similarity between R- values and fault-plane solu- 

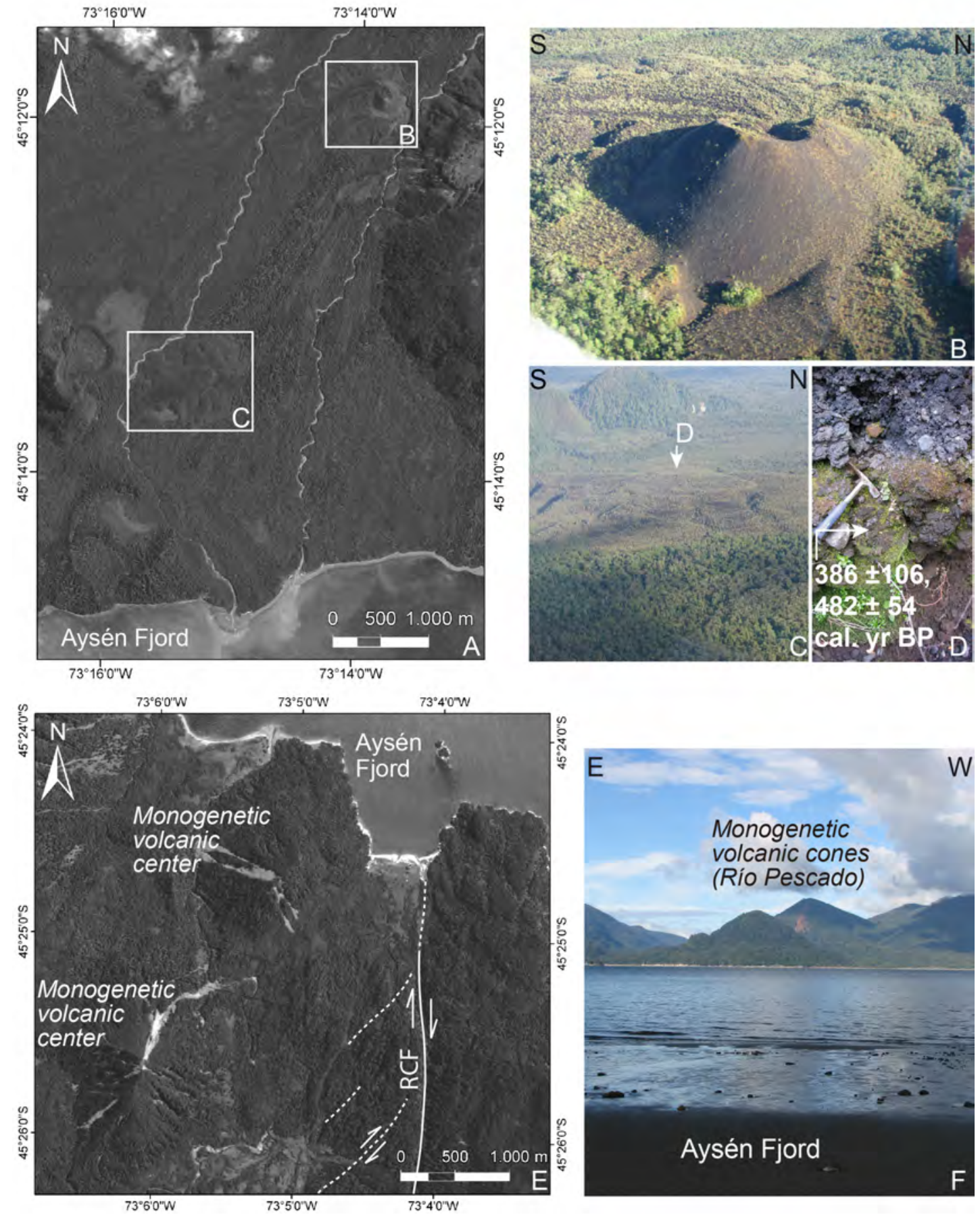

FIG. 13. SPOT satellite images and photographs of some of the monogenetic volcanoes in the study area. A-C. show the location of monogenetic centres in the area of Bahía Pérez, southwest from the Macá Volcano. $\mathbf{C}$ and $\mathbf{D}$ show the location of carbonized tree remains under a basaltic lava flow, associated with a poorly vegetated monogenetic centre dated by radiocarbon analyses. Calibrated radiocarbon results evidence the historical age of this centre (Table 1). $\mathbf{E}$ and $\mathbf{F}$ show monogenetic centres located at Pescado River, near the southern shoreline of the Aysén Fjord, in the area of the Río Cuervo Fault (RCF) and close to a volcanic conic structure within a submarine ridge shown in sub-bottom profiles (see text). White arrows represent inferred kinematics along the faults. 


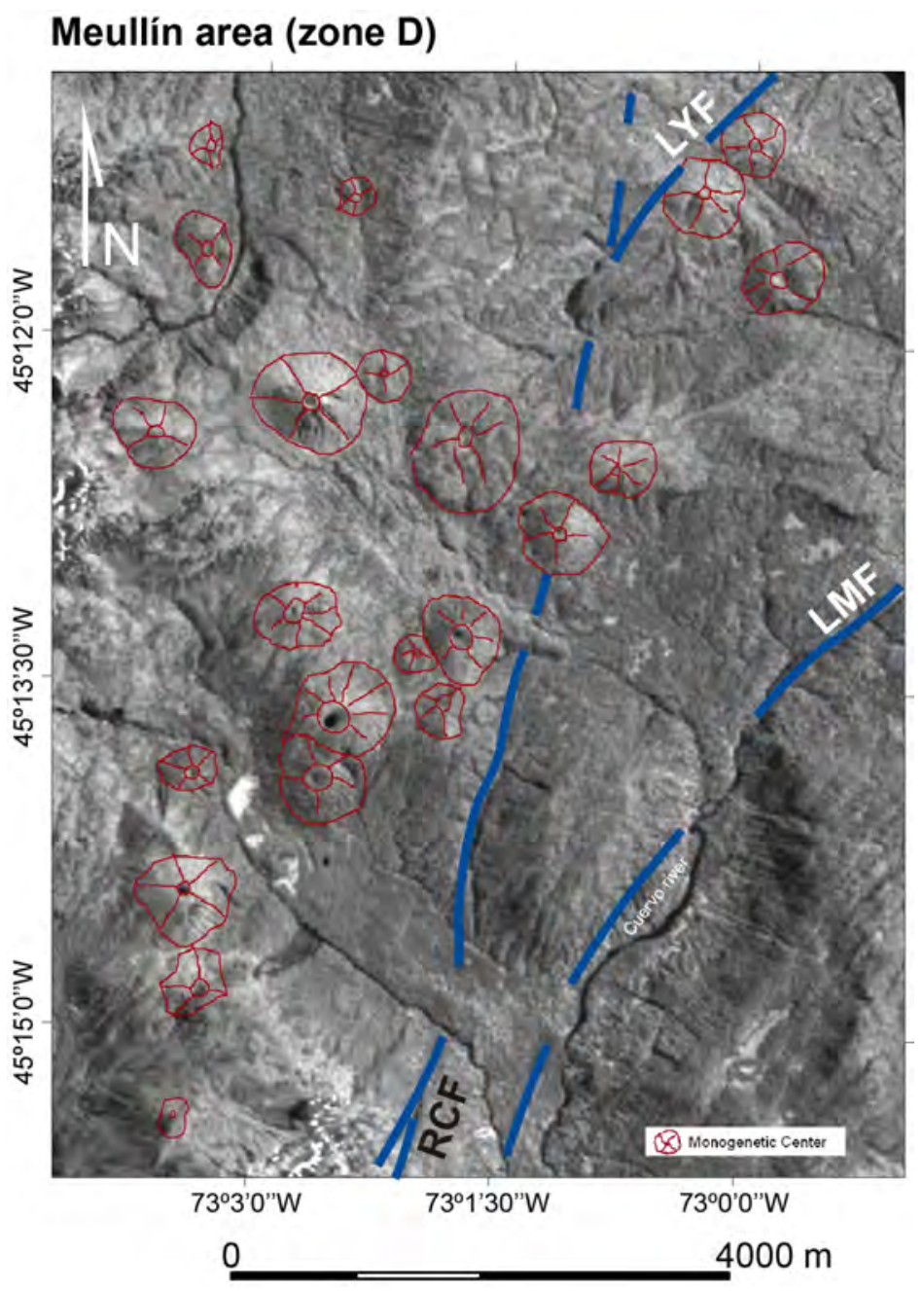

FIG. 14. SPOT image showing monogenetic cones in the Meullín area (zone D in figure 6a).

tions obtained from faults measurements in rocks and sediments (Figs. 8, 9 and 10), together with the striations affecting secondary minerals in some fault planes, suggest that mesoscale fault outcrops are exhumed fault systems that continuous active under similar tectonic regime at the scale of Late Pleistocene-Holocene. The overall data is consistent with a dominant transpressional regime driven by dominant NE-SW shortening during the Late Pleistocene and Holocene, as suggested previously for the late Cenozoic in the region (Hervé, 1994; Cembrano et al., 1999, 2002; Rosenau et al., 2006), which includes the development of duplex basins, crustal-scale pop-up structures, denudation and exhumation of granitoids along the LOFZ (Thompson,
2002). According to Lara et al. (2008), the coeval transpression or compression associated both with a NE-striking $\sigma 1$ along this major intra-arc fault zone can explain in part the vertical growth of the relief and associated volcanism. In the study area the different pattern that characterizes the positive relief along LPF, with respect to the geomorphology and associated volcanic centres along the RCF-LMF and LYF, could represent local differences in the context of a dominant transpression regime. Particularly, exhumation and fluid circulation along the main structures of the LOFZ seem to play a significant role in faulting mechanisms, as suggested by secondary minerals observed in fault planes in the area (Table 2). The focal mechanisms with N-S and NE-SW plane 
solutions obtained from most of the large shocks (Ms $>5$ ) during the last seismic event in the area (HRV, 2007; Legrand et al., 2011; Fig. 1), including the Mw6.2 main shock (Fig. 6), and those deduced from previous seismic surveys performed north of the study area (Lange et al., 2008), can be explained in the context of this fault kinematics. Furthermore, Quaternary neotectonics associated to fault kinematics and regional denudation, landslides, fluvial and volcanic geomorphologic processes have overprinted conspicuous glacial landforms, controlling most of the latest Pleistocene-Holocene geomorphologic evolution of the valleys in the study area (Fig. 6).

Most of the monogenetic volcanoes occurred clustered along NE to NNE-striking faults as shown by the geological mapping (Fig. 6), which coincides with the maximum stress direction deduced from the fault geometry in the area. Additionally, results from the morphometric analysis of the cones evidenced that most of them exhibit elongated cone bases along NE-striking directions as well as along north-south (Fig. 15). These observations support the idea that this kind of volcanic activity has been partly favoured by local extension along secondary faults or by inflections along master faults of the LOFZ, following Nakamura (1977); Lara et al. (2008) and Cembrano and Lara (2009), as in the case of the Meullín area (Fig. 6 and 14), where, in spite of large dispersion, most of the cones are slightly elongated and aligned along NNE and NE-striking directions. The geochemistry of some of this type of volcanoes in the region, which suggest the unevolved or poorly evolved character of the associated magmatism, could support this interpretation (D'Orazio et al., 2003; Gutiérrez et al., 2005). Additional research must be done to better constrain the possibility of this or other mechanisms for the origin of monogenetic cones in the area, like for example decompression melting along the LOFZ as suggested by Lara et al. (2008).

The different degree of erosion and vegetation cover of the monogenetic centres together with radiocarbon results from carbonized trees that gave historic ages (Table 1, Fig. 13), suggest that this volcanism has been intense throughout the Holocene, after the retreat of the last Late Pleistocene ice sheet in the area. This includes subaquatic centres inferred from the Aysén Fjord and Yulton Lake bottoms. From geomorphologic and radiocarbon data from the western flank of the Patagonian Andes, Denton et al. (1999) estimated last large development of piedmont

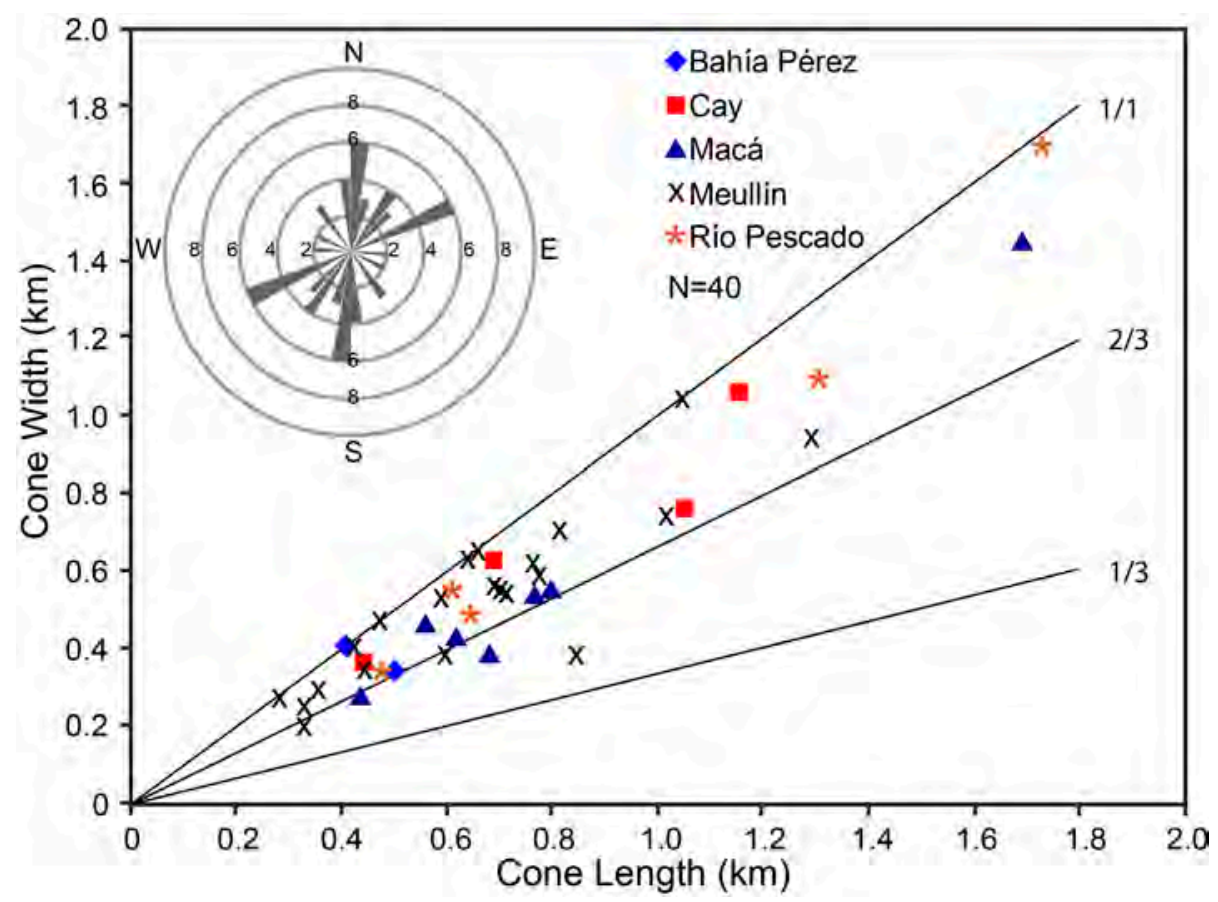

FIG. 15. Morphometric relationships between cone-length and cone-width from monogenetic centres in the study area, and directions of the main axis of the cone base from those centres. 

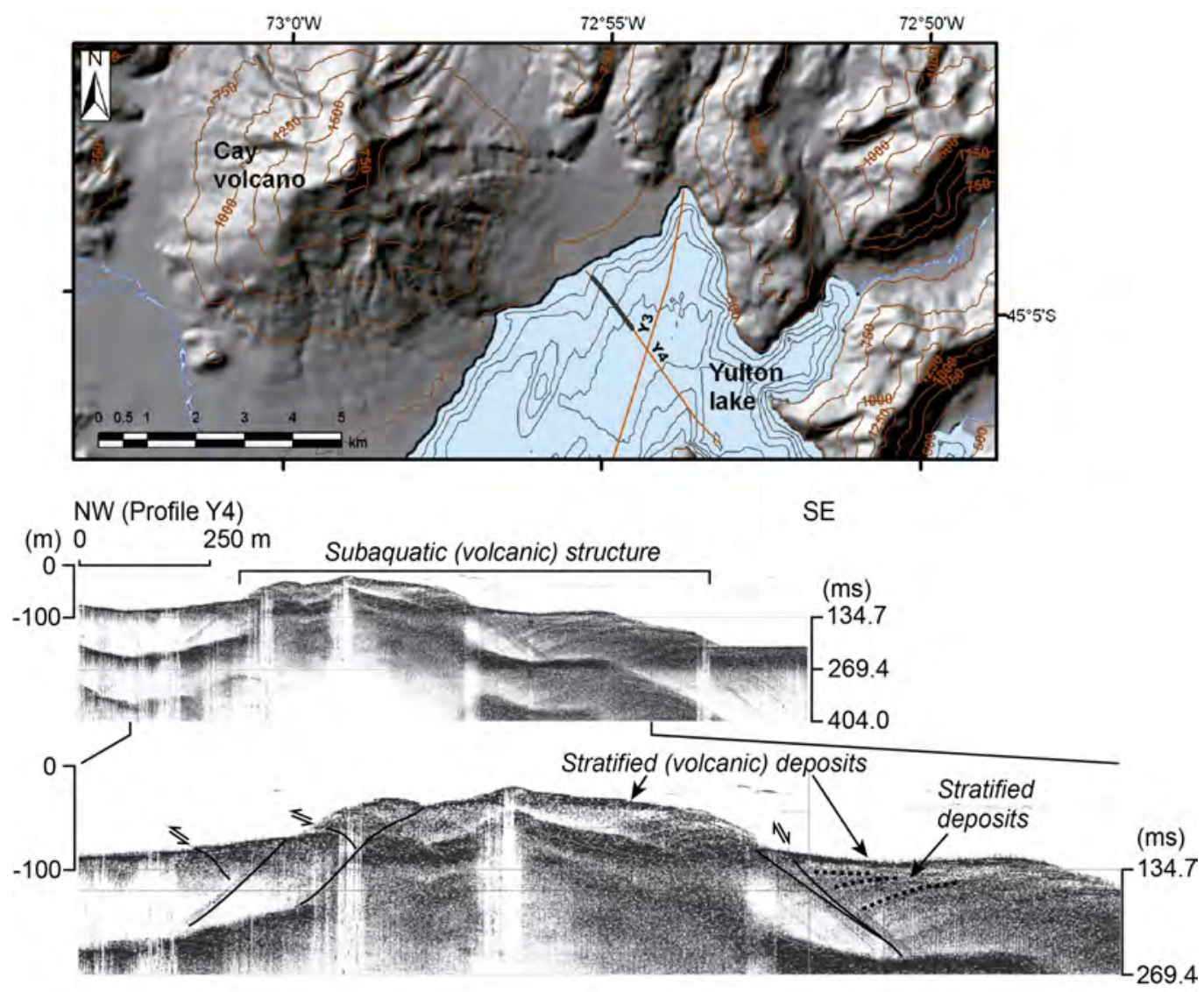

FIG. 16. Sub-bottom profile and bathymetric data from the Yulton Lake at the base of the SE flank of the Cay Volcano. The morphology and the internal structure of this feature are interpreted as the results of shallow subaquatic volcanism of possible fissure origin, flanked to the east by normal faults along the inferred Lago Yulton Fault system (LYF; Fig. 6).

glaciers at ca. $14.8 \mathrm{ka} \mathrm{BP}$ in the Llanquihue region at $41^{\circ} \mathrm{S}$, and Heusser (1990) inferred a sudden retreat of the Chilotan piedmont glaciers at $42-43^{\circ} \mathrm{S}$, at $c a$. 13 ka BP. In the study area, glacial retreat occurred before $12 \mathrm{cal}$. ka BP (10 ka BP), according to the new radiocarbon and geomorphologic observations concerning volcanic ash fall deposits directly overlying fluvial and outwash sediments located to the east of Puerto Aysén, provided in this work. Additionally, subbottom profiles provided indirect observations about the two units that constitute the sedimentary infill of the Aysén Fjord (Figs. 4 and 5). We interpret that massive to poorly stratified facies that characterize the Lower Unit can be associated in partly with glacial sediments (till and outwash deposits), but mostly with fluvial postglacial massive sandy sediments produced in a terrestrial environment just following the last ice sheet retreat in the area. The well stratified seismic facies that characterize the Upper Unit can be interpreted as the result of an alternated deposition of deltaic and marine sediments under subaquatic conditions that favoured the development and preservation of that type of deposits in a marine environment. Thus, since this Upper Unit is most probably associated with the supply of fluvial sediments from the main rivers in the area, mainly from the Aysén River, following classic sequential stratigraphy, it should represent the progradation of these sediments within the marine fjord basin during the Holocene global sea level highstand since $7 \mathrm{cal}$. ka BP (Lambeck et al., 2002). Considering that the submarine ridge in the Aysén Fjord acts as a barrier for sediments supplied by the Aysén River (Figs. 5 and 6), given that the strata that constitute the Upper Unit are onlapping the ridge (Fig. 5), and taking into account that the conic volcanic structure forming part of this ridge 
have not been affected by glacial erosion (Fig. 5), we interpret a postglacial-pre sea level highstand age for the formation of this submarine volcanic feature, possibly between $12 \mathrm{cal}$. ka BP and $7 \mathrm{cal}$. $\mathrm{ka} \mathrm{BP}$. A tectonic control on its origin is a reasonable possibility considering the close spatial association of this feature and other postglacial monogenetic cones with master faults of the LOFZ (Lara et al., 2008). Additional research is needed to better constrain the shape, nature and origin of this submarine feature, which is critic for the assessment of seismic and volcanic hazard in the Aysén Fjord. Several strata within deltaic sequences in the Cuervo River area forming a terrace located up to 8-10 $\mathrm{m}$ above the present-day sea level, with abundant remnants of trees and soils dated ca. 7750-8500 cal. years BP (Fig. 9), suggest episodes of marine flooding concomitantly with a rising shoreline close to the maximum global sea level high stand during the Holocene ca. $7 \mathrm{cal}$. ka BP (Lambeck et al., 2002). These observations allow us to estimate a minimum uplift rate of 1.1$1.4 \mathrm{~mm} / \mathrm{yr}$ during the last $7 \mathrm{ka}$. This rate is close to the average long-term denudation rates of $<0.4-0.9$ $\mathrm{mm} / \mathrm{yr}$ or $1 \mathrm{~mm} / \mathrm{yr}$, estimated from fission track results and hornblende geobarometry from Miocene and Pliocene plutons in the eastern blocks along the RCF by Thomson (2002) and Hervé et al. (1993, 1996), respectively. However, given that postglacial isostatic rebound has not been estimated in the area, it's difficult to estimate the tectonic/exhumation component associated to this minimum uplift rate and therefore further research is needed to estimate the contribution of these different processes to the Holocene uplifting in the area. Besides, right-lateral displacement of drainage systems deduced from SPOT imagery along the Riesco fault (Fig. 12), can be taken as preliminary evidence for dextral strike slip, following -for example- the tectonosedimentological process-response model for strike slip faults proposed by Sims (1994) and discussed by McCalpin et al., (2009). Although additional field investigations is needed to test this hypothesis, these observations suggest the possibility for Holocene dextral displacement of the local drainage systems in the order of hundreds of metres. Evidence for dextral strike-slip offsets of recent geomorphologic features are difficult to assess because of the high precipitation rates, erosion and vegetation cover in this region. Conversely, in a similar sense as stated by Lara et al. (2008), drainage and fluvial anomalies detected under this climate regime in the region should be very young. Assuming a maximum age of $c a .12$ cal. ka BP for these welldefined and preserved drainage networks (Fig. 12), Holocene dextral strike slip rate in the order of tens of $\mathrm{mm} / \mathrm{yr}$ could be roughly inferred Rosenau et al. (2006) inferred a southward increase in the mean Pliocene-Holocene dextral slip rates along the LOFZ, from $13 \pm 3 \mathrm{~mm} / \mathrm{yr}$ at $38^{\circ}-40^{\circ} \mathrm{S}$ to $32 \pm 6$ $\mathrm{mm} / \mathrm{yr}$ at $40^{\circ}-42^{\circ} \mathrm{S}$, due to increasing partitioning of the Nazca-South America plate convergence vector to the south. Lara et al. (2008) stressed the last estimation and proposed maximum strike-slip rates along the LOFZ in the order of $17-28 \mathrm{~mm} /$ yr due to an almost complete partitioning of the convergence vector along margin parallel faults. In this sense, our observation provide preliminary evidence for Holocene dextral strike-slip along a main fault system of the LOFZ in the study area that should be confirmed by more detailed geomorphologic analysis, aiming to better constrain the strike-slip component along active faults to improve seismic hazard assessment in the region.

The study area can be considered as a transference fault zone between regional N-S to NNE-striking fault systems along the LOFZ. As present day deformation occurs mostly along N-S and NE-SW to NNE-SSW main structures, the slip-rate along these faults are expected to be higher with respect to E-W faults (Fig. 6). This can imply a clockwise rotation of tectonic blocks located among the main fault systems in the area, resulting in a southern deflection of the eastern segments of the east-west fault systems, as suggested from the fault cartography (Fig. 6). According to our observations, most of the seismic events reported during the seismic swarm of 2007 (GUC, 2007; HRV, 2007; Legrand et al., 2011), occurred in a 6-8 km width fringe along the RCF, in the area of the junction with the Quitralco Fault (Figs. 1 and 6). Altogether, the focal mechanisms and the location of the largest earthquakes are consistent with the N-S and NE-striking dominant faults in the area, with dextral mechanism obtained for the $\mathrm{N}-\mathrm{S}$ and extensional mechanism for the NE-striking plane solution (HRV, 2007; Legrand et al., 2011). The observation of seismic data obtained from the local seismic network suggests that during the last seismic event on 2007, earthquakes were nucleated at maximum depths of 9-7 km (GUC, 2007; Barrientos et al., 2007; Mora et al., 2008; Legrand et al., 
2011), which are in the order of those deduced from previous seismic survey in the northern part of the LOFZ (Lange et al., 2008). These maximum focal depths are consistent with high geothermal gradient and thin upper crust (6-11 km), according to fission track-results from Miocene magmatic rocks (10 Ma) in the area of the Aysén Fjord (Thomson, 2002). Assuming $9 \mathrm{~km}$ depth for the brittle-seismogenic zone in the area, the Mw 6.2 earthquake occurred in April 2007 is coherent with a surface rupture length in the order of $15 \mathrm{~km}$, which is within the scale of the surface trace-length of the PCF, dipping about $80^{\circ} \mathrm{W}$ in the area of the Aysén Fjord and to the north (Figs. 6 and 8).

Scale relationships between faults and earthquakes (Scholz, 1982; Wells and Coppersmith, 1994), suggest that the Mw 6.2 seismic event could have entrained surface displacements of only few decimetres. Such a dimension is consistent with the scarcity of evidence of surface rupture that can be clearly associated to this earthquake in the study area. In spite of that, fresh fault scarps and fault planes were observed along the PCF, particularly at the southeastern limit of the largest landslide occurred in the ravine next to Punta Cola. Together with fresh submarine fault scarps observed at the fjord bottom in front of that area, these observations can be taken as evidences for surface seismic rupture along this fault system (Figs. 4 and 8). Surface displacements in the order of some decimetres during the last large seismic event appears to be out of scale with respect to 6-8 m high submarine fault scarps observed in sub-bottom profiles in the fjord bottom in front of Punta Cola (Fig. 4). This suggest that those submarine fault scarps observed in the area of the epicentre of the $2007 \mathrm{Mw} 6.2$ earthquake accumulates more than one seismic rupture, and thus could represents a cumulative process which includes the last seismic event and those previous that could have been recurrent during the last hundreds or thousands of years. Some historic chronicles related to one seismic episode occurred in 1927 -shortly after the foundation of the city of Puerto Aysén during the late 1920s- which was probably located at Canal Moraleda located to the west of he study area and that entrained landslides and tsunamis in the area of the Aysén Fjord (Greve, 1964; Naranjo et al., 2009), provide additional information for historic large events along the LOFZ in the region.

The fault cartography presented here suggests that major faults are composed of 20 - $30 \mathrm{~km}$ length active segments that can reach up $40 \mathrm{~km}$ length like in the case of the Río Cuervo Fault and Riesco Fault, implicating similar or greater potential seismic hazard in the region. Considering the possibility for a surface rupture length of $40 \mathrm{~km}$, earthquake in the order of Mw 7.1 could be expected in the area according fault geometry and kinematics of the main structures together with scale relationships between active faults and earthquakes (Wells and Coppersmith, 1994), at period of time of hundreds of years, if we take into account Slemmons and Depolo (1996) and inferences about the order of magnitude of slip rates discussed previously. Besides, most of the faults are composed of segments in the order of 10-20 km length, implicating potential earthquakes in the order of $\mathrm{Mw}$ 6.2-6.5 at period of time of dozens of years (Wells and Coppersmith, 1994; Slemmons and Depolo, 1996). This is particularly the case of Los Palos Fault defined in this work, which traverses the westernlimit of the city of Puerto Aysén, from which recent activity can be inferred from sub- bottom profile data (Figs. 6 and 11). Further research focused on paleoseismology, seismic and geodetic survey as well as modelling of fault seismic ruptures is needed to provide more precise estimation of seismic hazard especially for the city of Puerto Aysén in this key area of southern Chile. at can reach up to $40 \mathrm{~km}$ length like in the case of the Río.

\section{Concluding remarks}

Because of the steep mountains, dense vegetation cover, high precipitation rates and scarce access, the Aysén region of southern Chile is a difficult zone to develop neotectonic research and especially detailed mapping of active faults. From imagery, DEMs, field recognition, structural characterization, marine geology-techniques and radiocarbon geochronology, we performed geomorphologic analysis that resulted in a proposed cartography of active fault segments, monogenetic volcanic cones and recent kinematics, improving basic knowledge for seismic hazard assessment in the area of the Aysén Fjord, which is crucial for the sustainable development of the Patagonian Andes.

Our observations reveal a strong association between Holocene surface manifestations of active faulting, destructive crustal earthquakes and monogenetic volcanism along the Liquiñe-Ofqui Fault Zone (LOFZ) in the area of the Aysén Fjord. Geomorpho- 
logic observations and radiocarbon results presented here indicate that the last Pleistocene ice sheet retreat in this region occurred before $12000 \mathrm{cal}$. years BP. Exhumed fault outcrops and postglacial geological evidences including radiocarbon-dated Holocene sediments affected by faults are in agreement with a transpressive regime associated to a NE-SW shortening, that defined deformation along right lateral strike-slip N-S and locally NNW-striking faults with reverse component, which is in turn consistent with the development of pop-up structures at surface. Together with local extension along dominantly dextral SW-NE to NNE-striking faults, we interpret that this kinematics has controlled the origin of duplex structures favouring the development of pull-apart basins at Quaternary time scale, like the Yulton and Meullín Lakes, which geomorphologic evolution have also been driven by strong glacial erosion overprinted by fluvial, volcanic and landslide processes. In this context, the cartography of the Holocene monogenetic volcanic cones shows a close spatial association of most of these centres with the main fault systems in the area, especially with N-S and NE-striking faults. Together with their morphometric characterization, this is consistent with a tectonic control for the origin of a part of them. Calibrated radiocarbon results from carbonized tree remnants under a lava flow associated to one of the most recent monogenetic volcanic centres yielded ages between the years AD 1450 and 1670, indicating that this volcanism occurred even during historic times in the area. From the analysis of geomorphologic features together with calibrated radiocarbon results we estimate a minimum Holocene uplift rate in the order of 1.1-1.4 mm/yr in the eastern block located along the dextral N-S Río Cuervo Fault system, which is one of the major structures in the area. Some systematically deflected drainage networks observed from satellite imagery provided preliminary evidence for recent right lateral displacement, suggesting significant Holocene dextral strike slip along the main NE-striking Riesco Fault system.

Submarine fault scarps from sub-bottom profile data and surface neotectonics reveal that the large Mw 6.2 earthquake that affected the Aysén Fjord during 2007 was associated with a subvertical-dipping west 15-20 km long dextral strike-slip north-south structure, named Punta Cola Fault. This fault is located along an area that can be taken as a main north-south branch of the LOFZ, 6-8 km to the east of the major north-south Río Cuervo Fault system. Most of the epicentres of the seismic swarm that occurred between January and April 2007 were located along or in between these structures.

The cartography of active faults proposed in this work suggests that this area is a transference zone between main regional branches of the LOFZ, which implies potential seismic hazard in this portion of the Patagonian Andes, including the city of Puerto Aysén particularly associated to the active Los Palos Fault system proposed here. Our results, together with previous observations and scale relationships between active faults and earthquakes, suggest that large seismic events Mw 6.2-6.5 can be typically expected along most of the active structures, while earthquake magnitude in the order of 7.1 could be expected along the main fault systems like the Río Cuervo Fault.

\section{Acknowledgements}

This work was supported by Energía Austral. The authors gratefully acknowledge additional support from Millennium Nucleus on Seismotectonics and Seismic Hazard, International Earthquake Research Centre, Montessus de Ballore (CIIT-MB), Grant P06- 064-F, and CEGA (Andean Geothermal Centre of Excelence) Fondap Project 15090013. $3.5 \mathrm{kHz}$ sub-bottom profiler and marine geology facilities were provided by the Department of Geology, University of Chile. Fieldwork and applied scientific research were greatly assisted by C. Nuñez, S. Moreira and A. Maurín from Energía Austral, J. Castillo and L. Cares from Knight Piésold, together with crucial logistic support from J. Gangas, M. Contreras and field staff from Centro de Ecología Aplicada (CEA). We also thank the crew of the R/V Petrel of CONAF. A. Amigo, G. Orozco, J. Arriagada and T. Villaseñor provided additional support during fieldwork and/or data processing.

We gratefully acknowledge reviews from L. Lara, one anonymous reviewer, and the editor M. Suárez. Also, we thank useful comments to a first version of this manuscript from J. Cembrano. We thank M. Gardeweg and C. Lamperein who provided valuable comments with respect to the first results during the realization of the applied scientific research.

\section{References}

Adriasola, A.; Thomson, S.; Brix, M.; Hervé, F.; Stöckhert, B. 2006. Postmagmatic cooling and late Cenozoic denudation of the North Patagonian Batholith in the Los 
Lagos region of Chile, $41^{\circ}-42^{\circ} 15^{\prime} S$. In International Journal of Earth Sciences 95 (3): 504-528.

Allmendinger, R.W.; Cardozo, N.C.; Fisher, D. 2012. Structural Geology Algorithms: Vectors \& Tensors, Cambridge, England, Cambridge University Press: $289 \mathrm{p}$.

Angermann, D.; Klotz, J.; Reigber, C. 1999. Spacegeodetic estimation of the Nazca-South America Euler vector. Earth and Planetary Science Letters 171: 329-334.

Arancibia, G.; Cembrano, J.; LavenuA. 1999. Transpresión dextral y partición de la deformación en la Zona de Falla Liquiñe-Ofqui, Aisén, Chile (44-45오). Revista Geológica de Chile 26 (1): 3-22.

Barrientos, S.E.; Ward, S.N. 1990. The 1960 Chile earthquake: inversion for slip distribution from surface deformation. Geophysical Journal International 103: 589-598.

Barrientos, S.; Bataille, K.; Aranda, C.; Legrand, D.; Báez, J.C.; Agurto, H.; Pavez, A.; Genrich, J.; Vigny, C.; Bondoux, F. 2007. Complex sequence of earthquakes Fjordland, Southern Chile. In Proceedings Geosur, Abstract Volume: p. 21. Santiago.

Beck, S.; Barrientos, S.; Kausel, E.; Reyes, M. 1998. Source characteristics of historic earthquakes along the central Chile subduction zone. Journal of South American Earth Sciences 11: 115-129.

Cain, J.S.; Evans, J.P.; Forster, C. 1996. Fault zone architecture and permeability structure. Geology 24 (11): 1025-1028.

Cande, S.C.; Leslie, R.B. 1986. Late Cenozoic tectonics of the southern Chile Trench. Journal of Geophysical Research 91: 471-496.

Cembrano, J.; Hervé, F.; Lavenu, A. 1996. The LiquiñeOfqui fault zone: a long-lived intra-arc fault system in southern Chile. Tectonophysics 259: 55-66.

Cembrano, J.; Lavenu, A.; Arancibia, G.; López, G.; Sanhueza, A. 1999. Crustal-scale pop-up structure at the southern Andes plate boundary zone: A kinematic response to Pliocene transpression. In International Symposium on Andean Geodynamics (ISAG), No. 4, Abstract Volume: 151-154. Göttingen, Germany.

Cembrano, J.; Lavenu, A.; Reynolds, P.; Arancibia, G.; López, G.; Sanhueza, A. 2002. Late Cenozoic transpressional ductile deformation north of the Nazca-South America-Antarctica triple junction. Tectonophysics 354: 289-314.

Cembrano, J.; Lara, L.; Lavenu, A.; Hervé, F. 2007. Long-term and short-term kinematic history of the Liquiñe-Ofqui fault zone: a review and implications for geologic hazards assessment. In Proceedings Geosur, Abstract Volume: p. 30. Santiago.

Cembrano, J.; Lara, L. 2009. The link between volcanism and tectonics in the southern volcanic zone of the ChileanAndes: Areview. Tectonophysics 471: 96-113. doi: 10.1016/j.tecto.2009.02.038.

Cifuentes, I.L. 1989. The 1960 Chilean earthquakes. Journal of Geophysical Research 94: 665-680.

Cisternas, M.; Atwater, B.F.; Torrejón, F.; Sawai, Y.; Machuca, G. ; Lagos, M.; Eipert, A.; Youlton, C.; Salgado, I.; Kamataki, T.; Shishikura, M.; Rajendran, C.P.; Malik, J.K.; Rizal, Y.; Husni, M. 2005. Predecessors of the giant 1960 Chile earthquake. Nature 437: 404-407.

Clavero, J.; Arenas, M.; Naranjo, J.; Lara, L. 2008. Parameterization of earthquake-induced landslides for tsunami modelling in southern Chile. In Congreso Geológico Argentino, No. 17, Abstract Volume 1: p. 267. Salvador de Jujuy.

Comte, D.; Gallego, A.; Russo, R.; Murdie, R.; VanDecar, J. 2007. The Aysen (Southern Chile) 2007 seismic swarm: volcanic or tectonic origin? Eos Transactions, AGU 88 (23), Joint Assembly Supplement.

Corazzato, C.; Tibaldi, A. 2006. Fracture control on type, morphology and distribution of parasitic volcanic cones: An example from Mt. Etna, Italy. Journal of Volcanology and Geothermal Research 158: 177-194.

Demant, A.; Hervé, F.; Pankhurst, R.J.; Magnette, B. 1994. Alkaline and calc-alkaline Holocene basalts from minor volcanoes in the Andes of Aysén, southern Chile. In Congreso Geológico Chileno, No. 7, Abstract Volume: 1326-1330. Concepción.

DeMets, C.; Gordon, R.G.; Argus, D.F.; Stein, S. 1994. Effect of recent revisions to the geomagnetic reversal time scale on estimates of current plate motions. Geophysical Research Letters 21 (20): 2191-2194.

Denton, G.H.; Lowell, T.V.; Heusser, C.J.; Schlüschter, C.; Andersen, B.G.; Heusser, L.E.; Moreno, P.I.; Marchant, D.R. 1999. Geomorphology, stratigraphy, and radiocarbon chronology of Llanquihue drift in the area of the southern Lake District, Seno Reloncaví, and Isla Grande de Chiloé, Chile. Geografiska Annaler 81A (2): 167-229.

D’Orazio, M.; Innocenti, F.; Manetti, P.; Tamponi, M.; Tonarini, S.; González-Ferrán, O.; Lahsen, A.; Omarini, R. 2003. The Quaternary calc-alkaline volcanism of the Patagonian Andes close to the Chile triple junction: geochemistry and petrogenesis of volcanic rocks from the Cay and Maca volcanoes, Chile ( $\left.\sim 5^{\circ} \mathrm{S}\right)$. Journal of South American Earth Sciences 16: 219-242. 
Farías, M.; Vargas, G.; Tassara, A.; Carretier, S.; Baize, S.; Melnick, D.; Bataille, K. 2010. Land-Level Changes Produced by the Mw 8.8 2010. Chilean Earthquake. Science 329 (5994): p. 916. doi: 10.1126/ Science.1192094.

Forsythe, R.D.; Nelson, E. 1985. Geological manifestation of ridge collision: evidence for the Golfo de Penas, Taitao basin, southern Chile. Tectonics 4: 477-495.

Greve, F. 1964. Historia de la sismología en Chile. Instituto de Geofísica y Sismología, Universidad de Chile: 138 p.

Gutiérrez, F.; Gioncada, A.; González-Ferrán, O.; Lahsen, A.; Mazzuoli, R. 2005). The Hudson volcano and surrounding monogenetic centres (Chilean Patagonia): an example of volcanism associated with ridge-trench collision environment. Journal of Volcanology and Geothermal Research 145: 207-233.

GUC. 2007. Informe de últimos sismos con magnitud igual o superior a 3.0. Universidad de Chile, Servicio Sismológico Nacional(GUC). http://ssn.dgf.uchile.cl/ (visited during 2007 and 2008).

Hervé, M. 1976. Estudio geológico de la falla LiquiñeReloncaví en el área de Liquiñe: antecedentes de un movimiento transcurrente (Provincia deValdivia). In Congreso Geológico Chileno, No. 1, Actas 1: B39B56. Santiago.

Hervé, F.; Pankhurst, R.J.; Drake, R.; Beck, M.E.; Mpodozis, C. 1993. Granite generation and rapid unroofing related to strike-slip faulting, Aysén, Chile. Earth and Planetary Science Letters 120: 375-386.

Hervé, F. 1994. The Southern Andes between $39^{\circ}$ and $44^{\circ} \mathrm{S}$ latitude: the geological signature of a transpressive tectonic regime related to a magmatic arc. In Tectonics of the Southern Central Andes (Reutter, K.J.; Scheuber, E.; Wigger, P.J.; editors). Springer Verlag: 243-248.

Hervé, F.; Pankhurst, R.J.; Demant, A.; Ramírez, E. 1996. Age and Al-in-hornblende geobarometry in the North Patagonian batholith, Aysen, Chile: St. Malo, France. In International Symposium on Andean Geodynamics (ISAG), No. 3, Abstract Volume: 17-19. Orstom.

Heusser, C.J. 1990. Chilotan piedmont glacier in the southern Andes during the last glacial maximum. Revista Geológica de Chile 17 (1): 3-18.

HRV. 2007. Harvard Seismology (USA), Centroid Moment Tensor (CMT) Catalog, www.globalcmt.org

Kanamori, H. 1977. The energy release in great earthquakes. Journal of Geophysical Research 82: 29812987.
Kim, Y.-S.; Peacock, D.C.P.; Sanderson, D. 2004. Fault damage zones. Journal of Structural Geology 26: 503-517. doi:10.1016/j.jsg.2003.08.002.

Lahsen, A.; González-Ferrán, O.; Innocenti, F.; Manetti, P.; Mazzuoli, R.; Omarioni, R.; Tampóni, M.S. 1997. New occurrence of orogenic volcanism along Liquiñe-Ofqui fault system: the Río Pescado volcanic centers, Southern Andes (4530'S-730.' W). In Congreso Geológico Chileno, No. 8, Abstract Volume 1: 108-112. Antofagasta.

Lambeck, K.; Esat, T.M.; Potter, E.-K. 2002. Links between climate and sea levels for the past three million years. Nature 419: 199-206.

Lange, D.; Cembrano, J.; Rietbrock, A.; Haberland, C.; Dahm, V.; Bataille, K. 2008. First seismic record for intra-arc strike-slip tectonics along the Liquiñe-Ofqui fault zone at the obliquely convergent plate margin of the southern Andes. Tectonophysics 455: 14-24.

Lara, L.E.; Lavenu, A.; Cembrano, J.; Rodríguez, C. 2006. Structural controls of volcanism in transversal chains: resheared faults and neotectonics in Cordón Caulle-Puyehue area $\left(40.5^{\circ} \mathrm{S}\right)$, Southern Andes. Journal of Volcanology and Geothermal Research 158: 70-86.

Lara, L. 2008. Holocene submarine volcanoes in the Aysén fjord, Patagonian Andes (44ㅇ): Relations with the Liquiñe-Ofqui Fault Zone. In International Symposium on Andean Geodynamics (ISAG), No. 7, Abstracts Volume: 285-288. Nice.

Lara, L.; Cembrano, J.; Lavenu, A. 2008. Quaternary vertical displacement along the Liquiñe-Ofqui Fault Zone: Differential uplift and coeval volcanism in the southern Andes? In International Geology Review 50 (11): 975-993.

Lara, L. 2009. The 2008 eruption of the Chaiten Volcano, Chile: a preliminary report. Andean Geology 36 (1): 125-129.

Lavenu, A.; Cembrano, J. 1999. Compressional- and transpressional- stress pattern for Pliocene and Quaternary brittle deformation in fore arc and intra-arc zones (Andes of Central and Southern Chile). Journal of Structural Geology 21: 1669-1691.

Legrand, D.; Barrientos, S.; Bataille, K.; Cembrano, J.; Pavez, A. 2011. The fluid-driven tectonic swarm of Aysén Fjord, Chile (2007) associated with two earthquakes (Mw 6.1 and Mw 6.2) within the Liquiñe-Ofqui Fault Zone. Continental Shelf Research 31: 154-161.

Lomnitz, C. 1971. Grandes terremotos y tsunamis en Chile durante el periodo 1535-1955. Revista Geofísica Panamericana 1: 151-178. 
López-Escobar, L.; Kilian, R.; Kempton, P.; Tagiri, M. 1993. Petrography and geochemistry of Quaternary rocks from the Southern Volcanic Zone of the Andes between $41^{\circ} 30^{\prime} \mathrm{S}$ and $46^{\circ} 00^{\prime} \mathrm{S}$, Chile. Revista Geológica de Chile 20: 33-55.

López-Escobar, L.; Cembrano, J.; Moreno, H. 1995. Geochemistry and tectonics of the Chilean southern Andes Quaternary volcanism $\left(37^{\circ}-46^{\circ} \mathrm{S}\right)$. Revista Geológica de Chile 22 (2): 219-234.

McCalpin, J.P.; Rockwell, Th.K.; Weldon II, R.J. 2009. Paleoseismology of strike-slip tectonic environments. In Paleoseismology ( McCalpin, J.; editor). Academic Press, International Geophysics Series 95: 421-496. doi: 10.1016/S0074-6142(09)95006-9.

McCormac, F.G.; Hogg, A.G.; Blackwell, P.G.; Buck, C.E.; Higham, T.F.G.; Reimer, P.J. 2004. SHCal04 Southern Hemisphere Calibration 0-11.0 cal kyr BP. Radiocarbon 46: 1087-1092.

Madariaga, R.; Métois, M.; Vigny, Ch.; Campos, J. 2010. Central Chile finally breaks. Science 9 (328): 181-182.

Marrett, R.A.; Allmendinger, R.W. 1990. Kinematic analysis of fault-slip data. Journal of Structural Geology 12: 973-986.

Melnick, D.; Bookhagen, B.; Strecker, M.; Echtler, H. 2009. Segmentation of megathrust rupture zones from fore-arc deformation patterns over hundreds to millions of years, Arauco peninsula, Chile. Journal of Geophysical Research 114 (B01407): 23 p. doi:10.1029/2008JB005788.

Mora, C.; Comte, D.; Russo, R.; Gallego, A. 2008. Analysis of the January 23, 2007 Aysén swarm using joint hypocenter determination. In International Symposium on Andean Geodynamics (ISAG), No. 7, Abstracts Volume: 341-343. Nice.

Moreno, M.; Rosenau, M.; Oncken, C. 2010. 2010 Maule earthquake slip correlates with pre-seismic locking of Andean subduction zone. Nature 467: 198-202. doi: 10.1038/nature09349.

Moreno, H.; Naranjo, J.A. 2003. Mapa de peligros del volcán Llaima, Región de la Araucanía. Servicio Nacional de Geología y Minería, Chile, Carta Geológica de Chile, Serie Geología Ambiental 7, 1 mapa escala 1:75.000.

Mouslopoulou, V.; Walsh, J.; Andrew, N. 2009. Fault displacement rates on a range of timescales, Earth and Planetary Science Letters 278:186-197. doi:10.1016/j. epsl.2008.11.031.

Nakamura, K. 1977. Volcanoes as possible indicators of tectonic stress orientation: Principle and proposal. Journal of Volcanology and Geothermal Research 2: 1-16.
Naranjo, J. A.; Stern, C.R. 1998. Holocene explosive activity of Hudson volcano, southern Andes. Bulletin of Volcanology 59: 291-306.

Naranjo, J.A.; Arenas, M.; Clavero, J.; Muñoz, O. 2009. Mass movement-induced tsunamis: main effects during the Patagonian Fjordland seismic crisis in Aisén (4525’S), Chile. Andean Geology 36 (1): 137-145.

Naranjo, J.A.; Moreno, H. 2005. Geología del Volcán Llaima, Región de la Araucanía. Servicio Nacional de Geología y Minería, Carta Geológica de Chile, Serie Geología Básica 88, 1 mapa escala 1:50.000.

Pardo-Casas, F.; Molnar, P. 1987. Relative motion of the Nazca (Farallon) and South American plates since late Cretaceous times. Tectonics 6: 233-248.

Plafker, G.; Savage, J.C. 1970. Mechanism of the Chilean earthquakes of May 21 and 22, 1980. Geological Society of America Bulletin 81: 1001-1030.

Pankhurst, R.; Hervé, F.; Rojas, L.; Cembrano, J. 1992. Magmatism and tectonics in continental Chiloé, Chile (42 ${ }^{\circ}$ and $42^{\circ} 30^{\prime} \mathrm{S}$ ). Tectonophysics 205: 283-294.

Reich, M.; Zúñiga, A.; Amigo, A.; Vargas, G.; Morata, D.; Palacios, C.; Parada, M.A.; Garreaud, R. 2009. Formation of cristobalite nanofibers during explosive volcanic eruptions. Geology 37 (5): 435-438. doi: 10.1130/G25457A.1.

Rosenau, M.; Melnick, D.; Echtler, H. 2006. Kinematic constraints on intra-arc shear and strain partitioning in the southern Andes between $38^{\circ} \mathrm{S}$ and $42^{\circ} \mathrm{S}$ latitude. Tectonics 25(TC4013). doi:10.1029/2005TC001943.

Scholz, C.H. 1982. Scaling laws for large earthquakes: consequences for physical models. Bulletin of the Seismological Society of America 72: 1-14.

Sepúlveda, S.A.; Serey, A. 2009. Tsunamigenic, earthquake-triggered rock slope failures during the 21st of April 2007 Aisén earthquake, Southern Chile $\left(45.5^{\circ} \mathrm{S}\right)$. Andean Geology 36 (1): 131-136.

Sepúlveda, S.A.; Serey, A.; Lara, M.; Pavez, A.; Rebolledo, S. 2010. Landslides induced by the 2007 Aysen Fjord earthquake, Chilean Patagonia. Landslides 7: 483-492

Sims, J.D. 1994. Stream channel offset and abandonment and a 200-year average recurrence interval of earthquakes on the San Andreas fault at Phelan Creeks, Carrizo Plain, California. In Proceedings of the workshop on paleoseismology (Prentice, C.S.; Schwartz, D.P.; Yeats, R.S.; editors). United States Geological Survey Open-File Report 94 (568): 170-172.

Slemmons, B.D.; Depolo, C. 1996. Evaluation of active faulting and Associated Hazards (Wallace, R.E.; editor). In Studies in Geophysics, active Tectonics. 
Proceedings of the National Academy of Sciences, Chapter 3: 45-62. Washington, DC.

Somoza, R. 1998. Updated Nazca (Farallon)-South America relative motion during the last $40 \mathrm{My}$ : implications for the mountain building in the central Andean region. Journal of South American Earth Sciences 11 (3): 211-215. doi:10.1016/S08959811(98)00012-1.

Stern, C.R.; Skewes, M.A.; Duran, M. 1976. Volcanismo Orogénico en Chile Austral. In Congreso Geológico de Chile, No. 1, Abstracts Volume 2: 195-212. Santiago.

Stern, C. R. 2004. Active Andean volcanism: its geologic and tectonic setting. Revista Geológica de Chile 31 (2): 161-206.

Stern, C.R.; Moreno, H.; López-Escobar, L.; Clavero, J.; Lara, L.E.; Naranjo, J.A.; Parada, M.A.; Skewes, A. 2007. Chilean volcanoes. In The Geology of Chile (Moreno, T.; Gibbons, W.; editors). The Geological Society of London, Chapter 5: 149-180.

Stuiver, M.; Reimer, P.J. 1993. Radiocarbon 35: 215-230.

Tapponnier, P.; Ryerson, F.J.; Van der Woerd, J.; Mériaux, A.-S.; Lasserre, C. 2001. Long-term slip rates and characteristic slip: keys to active fault behaviour and earthquake hazard. Earth and Planetary Sciences 333: 483-494.

Tibaldi, A. 1995. Morphology of pyroclastic cones and tectonics. Journal of Geophysical Research 100 (B12): 521-535.

Thomson, S. 2002. Late Cenozoic geomorphic and tectonic evolution of the Patagonian Andes between latitudes $42^{\circ} \mathrm{S}$ and $46^{\circ} \mathrm{S}$ : An appraisal base don fission-track results from the transpressional intraarc Liquiñe-Ofqui fault zone. Geological Society of America Bulletin 114 (9): 1159-1173.

Thomson, S.; Brandon, M.; Tomkin, J.; Reiners, P.; Vásquez, C.; Wilson, N. 2010. Glaciation as a des- tructive and constructive control on mountain building. Nature 467: 313-317. doi:10.1038/nature09365.

Vargas, G.; Farías, M.; Carretier, S.; Tassara, A.; Baize, S.; Melnick, D. 2011. Coastal uplift and tsunami effects associated to the $2010 \mathrm{Mw}$ 8.8 Maule earthquake in Central Chile. Andean Geology 38 (1): 219-238.

Vigny, C.; Socquet, A.; Peyrat, S.; Ruegg, J.-C.; Métois, M.; Madariaga, R.; Morvan, S.; Lancieri, M.; Lacassin, R.; Campos, J.; Carrizo, D.; Bejar-Pizarro, M.; Barrientos, S.; Armijo, R.; Aranda, C.; ValderasBermejo, M.-C.; Ortega, I.; Bondoux, F.; Baize, S.; Lyon-Caen, H.; Pavez, A.; Vilotte, J.P.; Bevis, M.; Brooks, B.; Smalley, R.; Parra, H.; Baez, J.-C.; Blanco, M.; Cimbaro, S.; Kendrick, E. 2011. The $2010 \mathrm{Mw}$ 8.8 Maule Megathrust Earthquake of Central Chile, Monitored by GPS. Science 332: 1417-1421. doi: 10.1126/science.1204132.

Wang, K.; Hu, Y.; Bevis, M.; Kendrick, E.; Smalley, R.; Vargas, R.B.; Lauría, E. 2007. Crustal motion in the zone of the 1960 Chile earthquake: Detangling earthquake-cycle deformation and forearc-sliver translation. Geochemistry, Geophysics, Geosystems $\left(G^{3}\right) 8$ (10): Q10010. doi: 10.1029/2007GC001721.

Wells, D.L.; Coppersmith, K.J. 1994. New empirical relationships among Magnitude, Rupture Length, Rupture Width, Rupture Area, and Surface Displacement. Bulletin of the Seismological Society of America 84 (4): 974-1002.

Yugsi Molina, F.; Oppikofer, T.; Hermanns, R.L.; Redfield, T.F.; Bascuñán, I.; Loew, S.; Sepúlveda, S.A. 2012. Mechanism and volume estimation of the 2007 Punta Cola rockslide-debris avalanche using terrestrial laser scanning and aerial photogrammetry. In Landslides and Engineered Slopes: Protecting Society through improved Undestanding (Eberhardt, E.; Froese, C.; Turner, A.K.: Leroueil, S.; editors). Taylor and Francis Group 1: 553-559. 